[Radiocarbon, Vol. 8, 1966, P. 161-203]

\title{
ISOTOPES, INC. RADIOCARBON MEASUREMENTS V
}

\author{
MILTON A. TRAUTMAN and ERIC H. WILLIS
}

Isotopes, Inc., Westwood, New Jersey

\section{INTRODUCTION}

This list presents dates on samples measured at Isotopes, Inc., during the years 1963 to 1965 and measurements made previously for which sample data has been recently received. The many results which do not appear are withheld pending additional information or at the request of our clients.

Procedures employed in sample pretreatment, preparation of $\mathrm{CO}_{2}$, and method of counting are generally unchanged, as are our methods of age calculation. Suitable bone samples are now pretreated by the method of Berger, Harney and Libby (1964).

In May, 1965, the three counters and associated electronics previously described (Isotopes I, II, III) were retired after producing well over 2000 radiocarbon dates, geophysical measurements, and ultralowlevel $\mathrm{C}^{14}$ measurements. A completely new laboratory was activated employing four new counters. Shielding consists of $31 \mathrm{~cm}$ of selected lowbackground steel, $10 \mathrm{~cm}$ paraffin and $2.5 \mathrm{~cm}$ "aged" lead. Each counter has its own multianode annular anticoincidence geiger counter. Electronics were designed and fabricated at Isotopes, Inc. The counters have an active volume of $1 \mathrm{~L}$ and when operated at a normal pressure of 3 atm, yield background counts of slightly over 2 counts $/ \mathrm{min}, \mathrm{A}_{\mathrm{Ox}} \times 0.95$ is ca. 18.7 at $24^{\circ} \mathrm{C}$.

$\mathrm{C}^{13} / \mathrm{C}^{12}$ ratios are measured periodically by our mass spectrometry section, but not routinely on samples unless requested by clients.

\section{ACKNOWLEDGMENTS}

It is recognized that data obtained at Isotopes, Inc. remain the sole property of our clients. We are indebted to those who have consented to have their data published here, and particularly to those supplying the comments on the ages.

The laboratory operations have been supervised throughout by Charles Tucek, and to him and his assistants, J. Bonicos, C. Tatsch, and E. Stapleton we are greatly indebted. We would particularly like to thank Miss Joan Gaetjen for her singular help in the task of assembling the mass of data associated with this date list.

\section{GEOLOGIC SAMPLES}

\section{A. Alaska}

\section{Upper Tanana River Valley series, Alaska}

Samples from Upper Tanana River Valley, Alaska. Coll. and subm. between 1959 and 1961 by A. T. Fernald, U.S. Geol. Survey, Washington. 


\section{I-305. Tahamund Lake, Alaska}

Woody material from exposed alluvial-colluvial material in bluff bordering Tahamund Lake (62 $45^{\prime} \mathrm{N}$ Lat, $141^{\circ} 42^{\prime} \mathrm{W}$ Long), Alaska. Comment (A.T.F.): sample provides date for accumulation of material in middle section of bluff.

\section{I-303. Nabesna River Flood Plain, Alaska}

$$
1270 \pm 80
$$

Peat from within flood-plain deposits of the Nabesna River $\left(62^{\circ} 57^{\prime}\right.$ $\mathrm{N}$ Lat, $141^{\circ} 58^{\prime} \mathrm{W}$ Long), Alaska. Comment (A.T.F.): sample provides date of flood-plain deposition at site.

\section{I-302. Nabesna River, Alaska}

$$
11,250 \pm 250
$$

9300 B.c.

Woody material from thin organic zone between dune sand in low bluff along Nabesna River ( $61^{\circ} 01^{\prime} \mathrm{N}$ Lat, $141^{\circ} 55^{\prime} \mathrm{W}$ Long), Alaska. Comment (A.T.F.) : dune at locality was stabilized during late Wisconsin time and subsequently reactivated.

\section{I-278. Midway Lake, Alaska, No. 1}

$850 \pm 90$

Woody material from exposed lacustrine silt and clay in a low bluff bordering Midway Lake (63 $13^{\prime} \mathrm{N}$ Lat, $142^{\circ} 16^{\prime} \mathrm{W}$ Long), Alaska. Comment (A.T.F.): date relates to lake that once covered this locality.

\section{I-277. Midway Lake, Alaska, No. 2}

$5300 \pm 250$

Peat from exposed loess and alluvial-colluvial material in bluff at same site as I-278. Comment (A.T.F.): dates accumulation of material in upper section of bluff.

\section{I-274. Tetlin Lake, Alaska}

$3000 \pm 120$

Woody material from exposed lacustrine silt and clay in a low bluff near Tetlin Lake (63 $07^{\prime} \mathrm{N}$ Lat, $142^{\circ} 39^{\prime} \mathrm{W}$ Long), Alaska. Comment (A.T.F.) : date relates to lake that covered the locality.

\section{I-279. Fish Lake, Alaska}

$2400 \pm 100$

450 B.c.

Woody material from exposed lacustrine silt and clay in a low bluff bordering Fish Lake (62 $58^{\prime} \mathrm{N}$ Lat, $141^{\circ} 50^{\prime} \mathrm{W}$ Long), Alaska. Comment (A.T.F.): date relates to lake that once covered this locality.

\section{Naknek drainage, pollen profile series, Alaska}

Samples from Naknek drainage area dated in order to provide evidence of the climatic sequence in the area of research. Coll. 1961 by D. E. Dumond, Univ. of Oregon, Eugene, Oregon; subm. 1961 by L. S. Cressman, Univ. of Oregon, Eugene, Oregon. Pollen analysis of material performed by C. J. Heusser, Am. Geog. Soc., New York, New York. 
Peat from basal section of bog on $\mathrm{N}$ bank near mouth of Naknek River ( $58^{\circ} 44^{\prime} \mathrm{N}$ Lat, $157^{\circ} 02^{\prime} \mathrm{W}$ Long), Alaska. Sampled from $2.1 \mathrm{~m}$ below surface of bog and ca. $15 \mathrm{~m}$ above mean high tide.

\section{I-528. Brooks River, Alaska, $1.5 \mathrm{~m}$}

$4800 \pm 175$

I-529. Brooks River, Alaska, $2.5 \mathrm{~m}$

2850 B.C.

Peats from bog on W bank upper Brooks River $\left(58^{\circ} 35^{\prime} \mathrm{N}\right.$ Lat, $155^{\circ}$ $44^{\prime} \mathrm{W}$ Long), Alaska. I-528 from depth of $1.5 \mathrm{~m}$ below bog surface, I-529 from $2.5 \mathrm{~m}$ below surface. Bog is ca. $5 \mathrm{~m}$ below elevation of river. Comment (D.E.D.): samples I-506, I-528 are assigned by Heusser (Heusser, 1963), to late postglacial zone as was Y-931, $3860 \pm 90$ (Yale VII) . I-529 is assigned to boundary between hypsithermal and late postglacial zones. I-529 is only slightly above base of Brooks River bog and indicates that pollen sequence does not greatly predate 6000 B.P. Inasmuch as Brooks River bog lies upon areas covered by early postglacial lake which was ancestral to present Brooks and Naknek Lakes of Naknek drainage, it may also be concluded that date provides an indication of the time at which the ancestral lake subsided to the point where Brooks River, which drains Brooks Lake into Naknek Lake, was formed.

\section{I-462. Goodnews Bay, Alaska}

$11,500 \pm 250$

9550 в.C.

Peat from shore bluffs of Kuskokwim Bay $\left(58^{\circ} 53^{\prime} \mathrm{N}\right.$ Lat, $161^{\circ} 47^{\prime}$ W Long), $1 \mathrm{mi} \mathrm{N}$ of mouth of Salmon River. From base of sequence of peat and silt $12 \mathrm{ft}$ thick filling a kettle hole in till comprising outermost loop of the end moraine of ice that flowed SW out of Kilbuck Mountains through Goodnews Bay, then spread in a piedmont lobe on the then-dry floor of Bering Sea. Peat layer is slightly disturbed as though it had accumulated before ice had completely melted out of the underlying drift; thus, it is believed to have accumulated shortly after ice retreated from this terminal position. Coll. 1957 and subm. 1961 by D. M. Hopkins, U. S. Geol. Survey, Washington. Comment (D.M.H.): date establishes that outermost Wisconsin moraines in Goodnews Bay area are of "classical" Wisconsin rather than Iowan age.

$$
560 \pm 75
$$

\section{I-439. Yakutat, Alaska}

A.D. 1390

Wood (Picea) $3 \mathrm{ft}$ above high tide line in sea cliff $0.75 \mathrm{mi} \mathrm{SE}\left(50^{\circ}\right.$ $32^{\prime} \mathrm{N}$ Lat, $139^{\circ} 51^{\prime} \mathrm{W}$ Long) of Ocean Cape at entrance to Yakutat Bay, Alaska. From stump rooted in 3 in. organic layer (peat) beneath clay till. Stump is sheared off at contact between peat and till. Coll. 1958 and subm. 1959 by D. J. Miller, U. S. Geol. Survey, Washington. Comment (D.J.M.) : the end moraine at the mouth of Yakutat Bay records the last 
advance of ice to the mouth of the bay, interpreted from a previous date (W-559, $830 \pm 160$, USGS V) as occurring no earlier than 1000 B.P. Present sample from ice-sheared stump below the youngest till should date more precisely the last advance and will provide the first direct check on radiocarbon dating of recent events in the Gulf of Alaska Tertiary province.

\section{I-440. Point Hope, Alaska}

Wood from log exposed in sea cliff along Arctic Coast $27 \mathrm{mi}$ SE $\left(68^{\circ}\right.$ $07^{\prime} \mathrm{N}$ Lat, $165^{\circ} 55^{\prime} \mathrm{W}$ Long) of Point Hope, Alaska. From top $1 \mathrm{ft}$ of $17.5 \mathrm{ft}$ thick marine gravel $40 \mathrm{ft}$ above present level of Chukchi Sea in platform cut onto Jurassic mudstone by the sea. Coll. 1958 and subm. 1959 by Ruben Kachadoorian, U. S. Geol. Survey, Menlo Park, California. Comment (R.K.): marine platform and gravels record last major high stand of Chukchi Sea in NE Alaska. Date is evidence that gravels were deposited during Sangamon age and can be correlated with Second Beach in the vicinity of Nome, Alaska.

\section{Barrow Beach Ridge series, Alaska} Alaska.

Peat samples from an inland beach ridge SE of Barrow Camp,

\section{I-1182. Barrow Ridge, Alaska, No. 1}

$1.8 \mathrm{mi} \mathrm{SE}$ of Barrow Camp $\left(71^{\circ} 19^{\prime} 10^{\prime \prime} \mathrm{N}\right.$ Lat, $156^{\circ} 36^{\prime} 15^{\prime \prime} \mathrm{W}$ Long), Alaska. Well-humified, buried peat layer 2 in. thick beneath $1 \mathrm{ft}$ of silt and overlying a relatively clean pea gravel. Exposed in 2nd trench S of U. S. Coast and Geodetic Survey station. Coll. 1963 by Jerry Brown and P. V. Sellman, U. S. Army Cold Regions Research and Engineering Lab., Hanover, New Hampshire; subm. 1963 by Jerry Brown.

\section{I-1183. Barrow Ridge, Alaska, No. 2}

$2.75 \mathrm{mi} \mathrm{SE}\left(71^{\circ} 18^{\prime} 25^{\prime \prime} \mathrm{N}\right.$ Lat, $156^{\circ} 35^{\prime} 40^{\prime \prime} \mathrm{W}$ Long) of Barrow Camp, Alaska. Frozen peat inclusion at depth of $3 \mathrm{ft}$, overlain by silty soil. Surface elevation $16 \mathrm{ft}$. Coll. 1962 by Jerry Brown and J. B. O’Sullivan, Allis-Chalmers, Milwaukee, Wisconsin; subm. 1963 by Jerry Brown.

\section{I-1384. Barrow Ridge, Alaska, No. 3}

$1.75 \mathrm{mi}$ SE of Barrow Camp, Alaska in shaft of U. S. Coast and Geodetic Survey seismic station. Sample from a thin ( $1 / 4$ in.), continuous layer of reworked and retransported organic fibers in a gravelly sand at depth of $7 \mathrm{ft}$. Surface elev 24 ft. Coll. 1964 by P. V. Sellman; subm. 1964 by Jerry Brown.

Comment (J.B.): date on I-1384 provides maximum age for upper $7 \mathrm{ft}$ of gravelly and silty sediment of beach ridge. Dates from 4 soil sites are 
available from this ridge: $A_{1}$ horizon of the well-drained Arctic Brown soil is $3000 \mathrm{yr}$ old (L-400A, Lamont V). Surface of beach ridge has been, therefore, stable for the past $3000 \mathrm{yr}$. I-1182 is probably a buried surface horizon of a paleo-Arctic Brown type soil. The abrupt contacts suggest burial by local eolian deposition for this site. Samples L-400B (11,050 \pm 350, Lamont V) and I-1183, from opposite ends of beach ridge further substantiate existence of an organic soil surface between 8700 and 11,000 B.P. Pollen analyses (Colinvaux, 1964) indicate a paucity or absence of alder pollen suggesting that burial of peat was prior to alder maximum (Porter, 1964), and probably close to 8300 B.P. (I-1202, this list). A burial mechanism by frost heave has been proposed (Douglass and Tedrow, 1960).

\section{Barrow Ice Wedge series, Alaska}

Plant fragments from buried ice wedge in ridge between Voth Creek and Village Slough Barrow ( $71^{\circ} 17^{\prime} 50^{\prime \prime} \mathrm{N}$ Lat, $156^{\circ} 42^{\prime} 25^{\prime \prime} \mathrm{W}$ Long), Alaska. Ice sample contained ca. 10 organic-rich, vertical foliations including leaves, stems, twigs, moss fragments, and lemming pellets. Organic residue collected by filtration from thawed ice. Coll. and subm. 1963 by Jerry Brown.

\section{I-922. Barrow Ice Wedge, No. 1}

From $11 \mathrm{ft}$ depth and just below I-701 (Isotopes IV).

\section{I-1171. Barrow Ice Wedge, No. 2}

$14,000 \pm 500$

From $12 \mathrm{ft}$ depth, $6 \mathrm{ft}$ from lateral contact of ice wedge, $12 \mathrm{ft} \mathrm{E}$ of I-922.

Comment (J.B.): organic residues were incorporated into ice through contraction-crack mechanism and were derived from surface vegetation and organic debris in the polygon troughs. Incorporation occurred prior to truncation and/or burial of ice mass. The two dates provide a period during which growth of the complex ice mass occurred (Brown, 1964). Pollen analysis of I-1171 (Colinvaux, 1964) indicated a severe Arctic climate ca. 14,000 в.P. Absence of present day pollen spectra in the ice substantiates lack of recent contamination. Dates provide additional evidence that present-day polygonal ground and active, surface ice wedges are of relatively young age (post-Wisconsin).

\section{I-1202. Barrow Topographic High}

$8330 \pm 250$

6380 в.C.

Buried soil peat from lowest peaty inclusion in perennially frozen silty sediment at $9 \mathrm{ft}$ depth, $2 \mathrm{mi} \mathrm{S}$ of Barrow Camp $\left(71^{\circ} 17^{\prime} 45^{\prime \prime} \mathrm{N}\right.$ Lat, $156^{\circ} 39^{\prime} 40^{\prime \prime}$ W Long), Alaska. Topographic high, with surface elev ca. $20 \mathrm{ft}$, is probably a weakly defined continuation of the inland beach ridge (Barrow Beach Ridge series, this list). Coll. 1959 by J. B. O'Sullivan; subm. 1963 by Jerry Brown. Comment (J.B.): this deep burial of 
masses of peat corresponds closely to events that caused burial of I-701 $(10,525 \pm 280$, Isotopes IV; Brown, 1964). It is postulated that a deep thaw occurred, followed by freeze-up of supersaturated sediments with the resulting burial. These events are probably associated with burial of peats in Barrow Ridge series (this list).

\section{I-1394. Gubik formation, Alaska}

Buried, retransported peat from $2.75 \mathrm{mi}$ SE of Barrow Camp $\left(71^{\circ}\right.$ $18^{\prime} 20^{\prime \prime} \mathrm{N}$ Lat, $156^{\circ} 35^{\prime} 30^{\prime \prime} \mathrm{W}$ Long), Alaska. Sample consists of several $1 / 4$ in. layers of reworked, retransported fibers at $49 \mathrm{ft}$ below sealevel (surface elev $49 \mathrm{ft}$ ) in frozen dark gray sands. Coll. and subm. 1964 by Jerry Brown. Comment (J.B.): date confirms that sediments are preWisconsin unit of Pleistocene Gubik formation. Black considers this unit at Barrow to be the Skull Cliff unit, of Illinoian age (Black, 1964). Date of $>38,000$ (W-380, Coulter, 1960) had been obtained for a log ca. $13 \mathrm{mi} \mathrm{SW}$ in what may be considered Wisconsin or Barrow Unit of the Gubik.

\section{I-437. Galena, Alaska}

$3250 \pm 150$

\section{B.C.}

Wood from a $24 \mathrm{ft}$ layer (channel fill) of frozen muck $206 \mathrm{ft}$ above Yukon River on "Cave-Off Cliffs," 6 mi up river from Galena Air Force Base, Alaska (64 $43^{\prime}$ N Lat, $156^{\circ} 44^{\prime} \mathrm{W}$ Long). Coll. 1954 and subm. 1962 by T. L. Péwé, U. S. Geol. Survey, College, Alaska. Comment (T.L.P.): Pleistocene mammal remains are reported from lower part of channel fill. Date suggests filling process continued until quite recently and did not terminate in the Pleistocene as originally suspected (Weber and Péwé, 1961a).

\section{B.c.}

Silty gyttja from pollen-dated core from Flora Lake $\left(63^{\circ} 29^{\prime} \mathrm{N}\right.$ Lat, $170^{\circ} 06^{\prime} \mathrm{W}$ Long), St. Lawrence Island, Alaska. Core consists of $1 \mathrm{~m}$ of lacustrine sediment overlying $1 \mathrm{~m}$ of buried soil. Sample is from $0.5 \mathrm{~m}$ from top of core. Coll. and subm. 1963 by P. A. Colinvaux, now at Dept. of Zoology and Entomology, Ohio State Univ., Columbus, Ohio. Comment (P.A.C.): date suggests unexpectedly great age of $11,000 \mathrm{yr}$ for the lake, indicating that underlying soil is of glacial and Bering land bridge age. Post-glacial pollen sequence consists of only two zones as at Imuruk Lake (Livingstone, 1955).

\section{B. Western United States}

\section{I-955. Butte County, Idaho}

Lignitic material from clay zone $1250 \mathrm{ft}$ below land surface ca. 46 mi W (43 $38^{\prime} 44^{\prime \prime} \mathrm{N}$ Lat, $112^{\circ} 55^{\prime} 02^{\prime \prime} \mathrm{W}$ Long) of Idaho Falls, Idaho. Coll. and subm. 1963 by W. S. Keyes, U. S. AEC, Idaho Operations Office, Idaho Falls, Idaho. 
I-423. Mesa Verde National Park, Colorado

$\geq \mathbf{3 5 , 5 0 0}$

Caliche from Cca horizon in face of large garbage pit on Chapin Mesa S of Mesa Verde Natl. Park Headquarters $\left(37^{\circ} 09^{\prime} 45^{\prime \prime} \mathrm{N}\right.$ Lat, $108^{\circ} 28^{\prime} \mathrm{W}$ Long), Colorado. Sampled from lowest level immediately above sandstone of the Cliff House (K) formation. Coll. and subm. 1961 by Douglas Osborne, U. S. Natl. Park Service, Mesa Verde Natl. Park, Colorado.

\section{I-698. Logan City Well, Main St., Utah}

$22,000 \pm 600$ 20,050 B.c.

Wood trash from $90 \mathrm{ft}$ level of City water well on E Main St. at junction of Canyon Road, Logan City $\left(41^{\circ} 43^{\prime} \mathrm{N} \mathrm{Lat}, 111^{\circ} 50^{\prime} \mathrm{W}\right.$ Long), Cache County, Utah. Taken by bailer from top of gravel aquifer. Much gas, apparently methane, escaped from the bed. Coll. and subm. 1962 by J. S. Williams, Physical Sciences Dept., Utah State Univ., Logan, Utah. Comment (J.S.W.): aquifer that contained sample could belong to Farmdalian interglacial and represent Bonneville-Provo I-Provo II interlake stade.

\section{I-697. Logan City Well, 6th $\mathrm{E}$ and $\quad 13,150 \pm 275$ 7th N Streets, Utah \\ 11,200 в.C.}

Wood trash from $150 \mathrm{ft}$ depth of city water well at NW corner of intersection of 7 th $\mathrm{N}$ and 6 th E Streets, Logan City $\left(41^{\circ} 44^{\prime} \mathrm{N}\right.$ Lat, $111^{\circ}$ 49' W Long), Cache County, Utah. Taken by bailer from top level of gravel aquifer. Coll. and subm. 1961 by J. S. Williams. Comment (J.S.W.): date indicates that gravels here at elev $4485 \mathrm{ft}$ are younger than in Main Street Well (I-698, this list) at $4452 \mathrm{ft}$, and may belong to Provo II-Provo III interlake stade.

\section{I-696. Willard Canal, Utah}

$10,300 \pm 275$ 8350 B.C.

Wood from Willard Canal, Station $320 \pm 50$, sec. 26, T7N, R2W, Salt Lake Base and Meridian, North Ogden $\left(41^{\circ} 19^{\prime} \mathrm{N}\right.$ Lat, $112^{\circ} 2^{\prime}$ $30^{\prime \prime} \mathrm{W}$ Long), Utah. Taken from bed of black coarse sand at water level in canal, $12 \mathrm{ft}$ below ground surface. Bed continues $\mathrm{S}$ for at least $300 \mathrm{ft}$ with wood fragments common. Coll. and subm. 1962 by J. S. Williams. Comment (J.S.W.): overlay is $12 \mathrm{ft}$ of clean, well-bedded mediumgrained sand with considerable crossbedding, probably representing last cycle of Lake Bonneville, Provo IV.

\section{I-1093. Ebeys Prairie, Washington}

\section{A.D. 1015}

$935 \pm 110$

Marine pelecypod shells from near top of 90 -ft bluff marking edge of terrace at Ebeys Prairie ( $48^{\circ} 12^{\prime} \mathrm{N}$ Lat, $122^{\circ} 43^{\prime} \mathrm{W}$ Long), $2 \mathrm{mi}$ SW of Coupeville, Whidbey Island, Washington, Shells occur in a horizon beneath 12 to 18 in. of black organic soil which is unfossilferous. Coll. and subm. 1963 by D. J. Easterbrook, Dept. of Geology, Western Washington State College, Bellingham, Washington. Comment (D.J.E.) : shells 
occur in what appears to be a marine terrace 80 to $100 \mathrm{ft}$ above present mean sealevel.

\section{Whidbey Interglacial sediments series, Washington}

Samples from interglacial deposits of the Whidbey formation which lie between the older Double Bluff and Possession units in Northern and Central Puget Lowlands (Easterbrook, 1965) . Coll. and subm. 1962 to 1965 by D. J. Easterbrook.

\section{I-722. Oak Harbor, Washington}

Wood from sea cliff along W side Whidbey Island, 5 mi SW of Oak Harbor at intersection of Willamette Meridian and Strait of Juan de Fuca $\left(48^{\circ} 15^{\prime} \mathrm{N}\right.$ Lat, $122^{\circ} 45^{\prime} \mathrm{W}$ Long). Taken from $\log 3 \mathrm{ft}$ in diam imbedded in sand beneath Vashon drift. Comment (D.J.E.): sample sets limiting date on accumulation of thick stratified section beneath Vashon drift on Whidbey Island and indicates that stratified deposits could not be outwash from advancing Vashon glacier.

\section{I-723. Crescent Beach, Washington}

Wood from sea cliff at Crescent Beach at $\mathrm{N}$ end of East Sound on Orcas Island (48 $42^{\prime} \mathrm{N}$ Lat, $122^{\circ} 53^{\prime} \mathrm{W}$ Long), Washington. Taken from poorly sorted, unstratified pebbly clay about $3 \mathrm{ft}$ above sealevel. Comment (D.J.E.): radiocarbon age is much greater than 11,500 B.P. expected based on stratigraphic relationships. Sediments may represent a remnant of a pre-Vashon section where Vashon drift and younger sediments have been eroded, or wood may have been reworked from older deposits.

\section{I-974. Guemes Island, Washington}

Peat from bed near top of sand and silty clay sequence overlain by gravel and Vashon till or glaciomarine drift at Yellow Bluff $\left(48^{\circ} 32^{\prime} \mathrm{N}\right.$ Lat, $122^{\circ} 39^{\prime} \mathrm{W}$ Long), Guemes Island, Washington. Comment (D.J.E.) : date indicates that these sediments are older than the interglacial which immediately preceded Vashon glaciation.

\section{I-975. Everett Gorge, Washington}

Peat from bed near middle of stratified sequence underlying Vashon till at Reservoir near Pigeon Creek ( $47^{\circ} 58^{\prime} \mathrm{N}$ Lat, $122^{\circ} 13^{\prime} \mathrm{W}$ Long), Everett, Washington. Comment (D.J.E.): sample from uppermost peat bed in pre-Vashon Everett Gorge section previously interpreted by Hansen and Mackin (Hansen and Mackin, 1949), as from an interglacial period earlier than the interglacial immediately preceding Vashon glaciation. Date tends to confirm this interpretation, but possibility that the interglacial immediately prior to the Vashon extended beyond 40,000 $\mathrm{yr}$ cannot yet be disproven. 
I-1194. Polnell Point, Washington

Peat from a bed which is part of a sand unit exposed in sea cliffs along Saratoga Passage, $1 \mathrm{mi} \mathrm{E}$ of Polnell Point $\left(48^{\circ} 17^{\prime} \mathrm{N} \mathrm{Lat}, 122^{\circ} 32^{\prime}\right.$ W Long), Whidbey Island, Washington. Comment (D.J.E.) : peat bed is overlain by glaciomarine drift and date indicates that sand unit probably belongs to Whidbey Formation and confirms interpretation that an unconformity exists between the unit and the overlying glaciomarine drift.

\section{I-1445. Swantown, Washington}

Wood from $\log$ ca. $5 \mathrm{ft}$ above sealevel in peat bed interbedded with sand and silt on $\mathrm{N}$ end of bluffs, $\mathrm{S}$ of Swantown $\left(48^{\circ} 17^{\prime} \mathrm{N}\right.$ Lat, $122^{\circ} 44^{\prime}$ W Long), Whidbey Island, Washington. Comment (D.J.E.): date correlates with other material from this formation.

I-1446. Penn Cove, Washington

Peat from bed a few $\mathrm{ft}$ above sealevel overlain by 10 to $20 \mathrm{ft}$ gravel and glaciomarine drift at Penn Cove (48 $14^{\prime} \mathrm{N}$ Lat, $122^{\circ} 43^{\prime} \mathrm{W}$ Long), E of Juan de Fuca, Whidbey Island, Washington, Comment (D.J.E.): this peat was previously dated $11,060 \pm 185$ (UW-33, unpub.). This date (I-1446) appears to be correct since stratigraphically the unit belongs to Whidbey Formation.

I-1528. Elger Bay, Washington

Peat from bed overlain by Vashon till at Elger Bay $\left(48^{\circ} 08^{\prime} \mathrm{N}\right.$ Lat, $122^{\circ} 28^{\prime}$ W Long), Camano Island, Washington. Comment (D.J.E.) : dates minimum age of Whidbey Formation on Camano Island.

\section{Puget Lowland series, Washington}

Samples of glaciomarine sediments deposited from floating ice in the Northern and Central Puget Lowland, Washington. They have been included in Everson Interstade of Fraser Glaciation, the last major glaciation of the lowland (Easterbrook, 1963a). Coll. and subm. 1963 to 1965 by D. J. Easterbrook.

\section{I-969. Orcas Island, Washington, No. 2 \\ $12,350 \pm 400$}

Shells (mostly Saxidomus) from fossiliferous glaciomarine drift 100 to $125 \mathrm{ft}$ above sealevel on $\mathrm{N}$ end of East Sound $\left(48^{\circ} 41^{\prime} \mathrm{N}\right.$ Lat, $122^{\circ} 56^{\prime}$ W Long), $1.5 \mathrm{mi}$ SW of town of East Sound. Comment (D.J.E.): shells occur in pebbly-clay till-like deposit containing pebbles transported by Canadian ice and deposited in marine water. Deposits correlate with glaciomarine drift younger than Vashon till in lowland near Bellingham.

I-1079. Whidbey Island, Washington, No. $2 \quad 10,585$ в.c.

Marine pelecypod shells from fossiliferous glaciomarine drift exposed in sea cliff 0 to $15 \mathrm{ft}$ above mean sealevel on West Beach $\left(48^{\circ} 14^{\prime}\right.$ 
N Lat, $122^{\circ} 46^{\prime}$ W Long), Whidbey Island, Washington. No overlying or underlying sediments exposed at site, but sample drift overlies Vashon till $0.5 \mathrm{mi} \mathrm{N}$. Comment (D.J.E.) : date establishes age of glaciomarine drift on Whidbey Island. Deposition was during a submergence occurring shortly after Vashon glaciation and correlates with similar deposits in N Puget and Fraser Lowlands (Easterbrook, 1962; 1963) .

\section{I-1035. Bellingham, Washington}

$10,370 \pm 300$

Wood from tree branch in small sand lens enclosed by fossiliferous glaciomarine drift at Bellingham (48 $46^{\prime} \mathrm{N}$ Lat, $122^{\circ} 28^{\prime} \mathrm{W}$ Long), Washington. Comment (D.J.E.): sample is from Bellingham glaciomarine drift overlying a sand unit and another glaciomarine drift in sea cliff exposures $2 \mathrm{mi} \mathrm{W}$. Date establishes age of submergence and deposition of Canadian-derived material by floating ice during latest phases of last major glaciation.

\section{I-1037. Nooksack Valley, Washington, No. 1}

Wood from SW bank of Nooksack River, 11/4 mi S of Mt. Baker Highway Bridge ( $46^{\circ} 52^{\prime} \mathrm{N}$ Lat, $123^{\circ} 17^{\prime} \mathrm{W}$ Long), Washington. Taken from near middle of Bellingham glaciomarine drift overlying ca. $30 \mathrm{ft}$ of Deming sand and $30 \mathrm{ft}$ of Kulshan glaciomarine drift. Comment (D.J.E.) : date establishes age of Bellingham glaciomarine drift and indicates that a very short time elapsed between deposition of Kulshan drift (W-996, 11,600 \pm 350 , USGS VII), Deming sand (W-940, 11,640 \pm 275 , USGS VII), and Bellingham glaciomarine drift.

\section{I-1447 Nooksack Valley, Washington, No. 2 -$$
\begin{aligned}
& 12,970 \pm 28 \\
& 11,020 \text { B.C. }
\end{aligned}
$$

Marine shells overlain by several feet of sand in glaciomarine drift $1 \mathrm{mi} \mathrm{SE}$ of Deming (48 $48^{\prime} \mathrm{N}$ Lat, $122^{\circ} 12^{\prime} \mathrm{W}$ Long), Washington. Comment (D.J.E.): dates extension of Kulshan glaciomarine conditions into Nooksack Valley.

\section{I-1448. Penn Cove Park, Washington}

$11,850 \pm 240$ 9900 B.c.

Shells in glaciomarine drift ca. $10 \mathrm{ft}$ above sealevel at Penn Cove Park (48 $14^{\prime} \mathrm{N}$ Lat, $122^{\circ} 40^{\prime} \mathrm{W}$ Long), Washington, (Easterbrook, 1965). Comment (D.J.E.): dates glaciomarine of Everson age on Whidbey Island.

\section{I-1469. Cattle Point, Washington}

$$
12,350 \pm 330
$$

Shells in glaciomarine drift overlying sand and gravel $1 \mathrm{mi} \mathrm{W}$ of Cattle Point $\left(48^{\circ} 14^{\prime} \mathrm{N}\right.$ Lat, $122^{\circ} 59^{\prime} \mathrm{W}$ Long), San Juan Island, Washington. 
$12,160 \pm 290$

I-1470. Davidson Head, Washington

10,210 B.c.

Shells in glaciomarine drift lying on Triassic bedrock at Davidson Head ( $48^{\circ} 37^{\prime} \mathrm{N}$ Lat, 123' $08^{\prime} \mathrm{W}$ Long), San Juan Island, Washington.

\section{I-1471. Little Sucia, Washington}

$12,000 \pm 450$

Shells from glaciomarine drift and associated sediments lying on Upper Cretaceous bedrock on Little Sucia Island $\left(48^{\circ} 46^{\prime} \mathrm{N}\right.$ Lat, $122^{\circ}$ $55^{\prime}$ W Long), Washington.

\section{I-1111. Strawberry Point, Washington}

$26,850 \pm 1700$

24,900 B.C.

Peat and wood from sea cliff, $1 / 4$ mi N of Strawberry Point $\left(48^{\circ} 18^{\prime}\right.$ $\mathrm{N}$ Lat, $122^{\circ} 30^{\prime} \mathrm{W}$ Long), Whidbey Island, Washington. Taken from peat bed lying on till ca. $5 \mathrm{ft}$ above sealevel. Peat marks base of sand unit ca. 80 to $100 \mathrm{ft}$ thick which is capped by Vashon drift.. Coll. and subm. 1963 by D. J. Easterbrook. Comment (D.J.E.): date indicates that till beneath peat is pre-Vashon and sets limiting age for overlying sand unit which is interpreted as early Vashon.

\section{I-1385. Pt. Roberts, W ashington}

$>35,000$

Wood from above unconformity at base of thick sand sequence capped by Vashon till at Point Roberts $\left(48^{\circ} 59^{\prime} \mathrm{N}\right.$ Lat, $123^{\circ} 01^{\prime} \mathrm{W}$ Long), 1 mi S of Maple Beach, Washington. Coll. and subm. 1964 by D. J. Easterbrook. Comment (D.J.E.): deposits correlate with Quadra Formation stratigraphically, but age of this sample makes the correlation uncertain.

I-1203. Useless Bay, Washington

Wood from sea cliff at $\mathrm{E}$ side Useless Bay $\left(47^{\circ} 58^{\prime} \mathrm{N}\right.$ Lat, $122^{\circ} 27^{\prime}$ $\mathrm{W}$ Long), 11/2 mi S of Sunlight Beach, Whidbey Island, Washington. Taken from till-like drift ca. $80 \mathrm{ft}$ above sealevel, overlain by sand and Vashon till. Coll. and subm. 1963 by D. J. Easterbrook. Comment (D.J.E.): date confirms interpretation of till as pre-Vashon and indicates that a glaciation of Puget Lowland occurred between deposition of underlying Whidbey Formation and last interglaciation. Site is one of few places where till occurs between Whidbey Formation and overlying sand unit.

\section{I-649. Heins Creek site, Wisconsin}

$$
200 \pm 75
$$

Burned wood fragments from Heins Creek site in sand dune area ( $45^{\circ} 01^{\prime} \mathrm{N} \mathrm{Lat}, 87^{\circ} 09^{\prime} \mathrm{W}$ Long), on coast of Lake Michigan, $41 / 4 \mathrm{mi} \mathrm{S}$ of Bailey's Harbor, Door County, Wisconsin. Coll. from buried humus zone, 1 to $2 \mathrm{ft}$ thick ca. $4 \frac{1}{2} \mathrm{ft}$ beneath aeolian sand and ca. $101 / 2$ $\mathrm{ft}$ above level of lake in a sand dune stabilized by heavy vegetation. Coll. 1961 and subm. 1962 by R. J. and C. I. Mason, Lawrence College, 
Appleton, Wisconsin. Comment (R.J.M.) : found in same stratum with triangular projectile points and pottery of early Late Woodland Heins Creek Complex, but date is too recent to provide age for archaeological material. Sample is likely from a much later intrusion and may provide maximum age for deposition and stabilization of overlying dune cap. I-678, $1230 \pm 150$ (Isotopes IV) which dates the archaeological material is considered reliable.

I-418. Gooseberry Anticline, Wyoming

Wood altered to coal (?) from small gray clay lens $12 \mathrm{ft}$ below surface inside of gully within old alluvium, in Gooseberry Anticline area, W 1/2, SW 1/4, SE 1/4, NE 1/4 sec. 33, T47 N, R100 W, 6th P.M., (44 N Lat, $108^{\circ} 51^{\prime} 40^{\prime \prime}$ W Long), Park County, Wyoming. Coll. and subm. 1960 by W. L. Rohrer, U. S. Geol. Survey, Washington.

\section{I-473. Dent Mammoth, Colorado, No. 1}

$7200 \pm 200$ 5250 B.C.

\section{I-622. Dent Mammoth, Colorado, No. 2}

$11,200 \pm 500$

Bone and tusk fragments from a young mammoth from Lindenmeier site (40 19' N Lat, $104^{\circ} 49^{\prime} \mathrm{W}$ Long), 2 mi SE of Milliken, Colorado. Removed and preserved with shellac during 1933 archaeological excavations. Sample provided by H. M. Wormington, Denver Mus. of Nat. His.; subm. 1961 by George Agogino and C. V. Haynes, Univ. of Arizona, Tucson, Arizona. Comment (C.V.H., G.A.): age on I-473 is inconsistent with geological and archaeological evidence which suggest age of 11,000 to 12,000 B.P. Sample was charred in an inert atmosphere prior to leaching with HCl. Indications are that all of shellac preservative was not removed by this pretreatment. A second aliquot of the sample (I-622) was ground to a fine powder, leached with alcohol and acetone, pyrolyzed, and leached with $\mathrm{HCl}$ prior to radiocarbon analysis. Date obtained on I-622 is consistent with geological estimate of age of Kersey terrace fill and with radiocarbon dating of Llano (Clovis) complex at Lehner site, Arizona. If terrace remnant at Dent is correlative with Corral Creek moraine, this date marks end of Corral Creek stade of Rock Mountain glaciation (Haynes and Agogino, 1960).

\section{I-449. U. P. Mammoth site, Wyoming}

$$
\begin{aligned}
& 11,280 \pm 350 \\
& 9330 \text { B.C. }
\end{aligned}
$$

Mammoth tusk from U. P. Mammoth site $\left(40^{\circ} 31^{\prime}\right.$ N Lat, $107^{\circ} 39^{\prime}$ W Long), $27 \mathrm{mi}$ SW of Rawlings, Wyoming. Partially articulated mammoth skeleton with associated artifacts occurred in clay and gravel channel fill overlain by fine grained alluvium. Tusks were only slightly mineralized. Coll. 1961 by George Agogino; subm. 1961 by Agogino, C. V. Haynes, Cynthia Irwin and Henry Irwin. Comment (G.A.): select interior portions of tusks were charred in an inert atmosphere and leached 
for $24 \mathrm{hr}$ in $\mathrm{HCl}$ prior to radiocarbon analysis. Sample dates the kill of a mammoth by man and suggests a Two Creeks age for lowest part of channel fill (Irwin et al., 1962).

\section{I-474. U. P. Mammoth site, Wyoming}

$4975 \pm 180$

3025 B.c.

Wood fragments from U. P. Mammoth site $\left(40^{\circ} 31^{\prime}\right.$ N Lat, $107^{\circ} 39^{\prime}$ W Long), $27 \mathrm{mi}$ SW of Rawlings, Wyoming. Sample from gravels containing mammoth bones and artifacts in channel fill and overlain by fine grained alluvium. Coll. 1961 by Cynthia and Henry Irwin; subm. 1961 by Henry Irwin, Cynthia Irwin, George Agogino and C. V. Haynes. Comment (G.A.) : age of sample suggests reworking of upper parts of channel fill and incorporation of the wood possibly during the Altithermal (Irwin et al, 1962).

\section{I-472. Brewster site, Wyoming}

$10,375 \pm 700$ 8425 B.c.

Wood charcoal from Brewster site ( $43^{\circ} 22^{\prime} \mathrm{N}$ Lat, $104^{\circ} 04^{\prime} \mathrm{W}$ Long), $3 \mathrm{mi}$ NE of Mule Creek Oil field, Wyoming. Coll. from basal portions of an alluvial fill and associated with Bison antiquus remains and Folsom artifacts. Coll. and subm. 1961 by C. V. Haynes and George Agogino. Comment (C.V.H.) : dates time of Folsom occupation contemporaneous with Bison antiquus and is consistent with dating of overlying Agate Basin occupation (M-1131, $9990 \pm 450$, Michigan VIII; O-1252, $9350 \pm$ 450, unpub.). Dates confirm geologic interpretation of post Two Creekspre-Altithermal channel fill and loess accumulations.

\section{Eastern United States}

\section{I-749. Frankford, Delaware}

$34,000 \pm 2000$

22,050 B.c.

Shell (Crassostrea virginica) in blue-black silt and fine sand of the outcrop of Omar Formation in Pepper Creek Ditch, $100 \mathrm{ft}$ E of Rt. 113 $\mathrm{N}$ of Frankford (38 $32^{\prime} \mathrm{N}$ Lat, $75^{\circ} 15^{\prime} \mathrm{W}$ Long), Delaware. Coll. 1962 and subm. 1963 by R. R. Jordan, Delaware Geol. Survey.

\section{I-854. Indian River Inlet, Delaware \\ $23,300 \pm 850$ \\ 21,350 в.C.}

Wood from core sample 126 to $127 \mathrm{ft}$ below land surface in well Pj 32-3, $60 \mathrm{ft} S$ of $S$ bank of inlet, $110 \mathrm{ft} E$ of Rt. 14, Indian River Inlet ( $38^{\circ} 36^{\prime} \mathrm{N}$ Lat, $75^{\circ} 04^{\prime} \mathrm{W}$ Long), Sussex Co., Delaware. Coll. 1962 and subm. 1963 by R. R. Jordan.

\section{I-747. Omar, Delaware}

Wood from $0.8 \mathrm{mi} \mathrm{E}$ of Omar, Sussex Co., Delaware on Rt. $54\left(38^{\circ}\right.$ $32^{\prime} \mathrm{N}$ Lat, $75^{\circ} 12^{\prime} \mathrm{W}$ Long). Core sample from $24 \mathrm{ft}$ below land surface (elev $22 \mathrm{ft}$ ) in well Qh 44-1, in quartz sand, fine, silty and clayey. Omar Formation. Coll. 1958 and subm. 1963 by J. J. Groot and R. R. Jordan, Delaware Geol. Survey. 


\section{I-284. Panama City, Florida}

$36,500 \pm 2000$

34,550 в.C.

Wood from submerged forest in $60 \mathrm{ft}$ of water on continental shelf off $\left(30^{\circ} 09^{\prime} \mathrm{N}\right.$ Lat, $85^{\circ} 48^{\prime} \mathrm{W}$ Long) Panama City, Florida. Trees stand vertical in a coarse, shelly, relict sand, but have been abraded off level with sea floor. Coll. and subm. 1961 by George Shumway, U. S. Navy Electronics Lab., San Diego, California.

\section{I-1747. Cape Fear River, N Carolina}

$14,000 \pm 250$ 12,050 B.c.

Peat from along $\mathrm{N}$ bank of Cape Fear River at Big Sugar Loaf Bluff (34 $37^{\prime} \mathrm{N}$ Lat, $78^{\circ} 31^{\prime} \mathrm{W}$ Long), Bladen County, N Carolina. 2.60 to $2.70 \mathrm{~m}$ from top of section in horizon intercalated in sands. Coll. and subm. 1965 by D. R. Whitehead, Biology Dept., Williams College, Williamstown, Mass. Comment (D.R.W.): pollen study of peat, correlated with this date, should contribute much to understanding of fullglacial conditions in SE N Carolina.

\section{I-1746 Intracoastal Waterway, N Carolina, $6.00 \mathrm{~m}$}

$$
\begin{aligned}
& 35,800 \begin{array}{r}
-3000 \\
+4200
\end{array} \\
& \text { 33,850 B.C. }
\end{aligned}
$$

Peat from along $\mathrm{S}$ bank of Intracoastal Waterway, $\mathrm{W}$ of Long Beach ( $33^{\circ} 55^{\prime} \mathrm{N}$ Lat, $78^{\circ} 09^{\prime} \mathrm{W}$ Long), Brunswick County, N Carolina. Upper of two peat horizons intercalated in fluvial sands. 6.00 to $6.40 \mathrm{~m}$ from top of section. Coll. and subm. 1965 by D. R. Whitehead. Comment (D.R.W.): see comment on I-1745, this list.

\section{I-1745. Intracoastal Waterway, N Carolina, $7.20 \mathrm{~m}$

$$
\begin{array}{ll}
36,000 & -2600 \\
& +3700 \\
34,050 \text { в.C. } &
\end{array}
$$

Peat from along $S$ bank of Intracoastal waterway, same locality as I-1746 (this list), but lower of two peat horizons, 7.20 to $7.40 \mathrm{~m}$ from top of section. Coll. and subm. 1965 by D. R. Whitehead. Comment (D.R.W.): peats at this locality are from deposits formerly considered interglacial and marine. Date is much too young to permit assignment to the Sangamon; and pollen evidence indicates fresh water conditions and a flora consisting of boreal and austral elements. Correlation with Port Talbot Interstadial seems likely.

\section{Canada}

Organic content of core No. 4 from E end of Squally Reach, Saanich Inlet $\left(48^{\circ} 35^{\prime} \mathrm{N}\right.$ Lat, $123^{\circ} 30^{\prime} \mathrm{W}$ Long), British Columbia. From $1940 \mathrm{~cm}$ below sediment interface in recent marine sediments. No fossils except for remains of planktonic diatoms. Coll. and subm. 1962 by S. M. Gucluer, J. S. Creager, M. G. Gross, Univ. of Washington, Seattle. 
Comment (M.G.G.): demonstrated sedimentation rate of ca. $6 \mathrm{~mm} / \mathrm{yr}$ is consistent with sedimentation rate obtained from average varve thickness (Gross et al., 1963).

\section{I-773. Wood River, British Columbia}

$22,900 \pm 1500$

Wood from $475 \mathrm{ft}$ above Columbia River and $10 \mathrm{ft}$ below ground surface in lens of blue-grey organic silt in glacial till near confluence of Columbia and Wood rivers $\left(52^{\circ} 07^{\prime} \mathrm{N}\right.$ Lat, $118^{\circ} 24^{\prime} \mathrm{W}$ Long), E central British Columbia. Coll. 1962 and subm. 1963 by F. Mylrea, CASECO Consultants, Ltd., Vancouver, British Columbia. Comment (F.M.) : glacial till above sample horizon was probably deposited at end of Pleistocene.

\section{North Greenland series}

Samples from raised beaches in N Greenland. Coll. and subm. 1960 to 1961 by W. E. Davies and D. B. Krinsley, U. S. Geol. Survey, Washington.

\section{I-306. Kap Trend, $\mathbf{N}$ Greenland}

$4860 \pm 150$

Wood from raised marine beach alt $89 \mathrm{ft}$ at Kap Trend, Danmark Fjord $\left(80^{\circ} 45^{\prime} \mathrm{N}\right.$ Lat, $23^{\circ} 45^{\prime} \mathrm{W}$ Long). Sampled from driftwood log on beach consisting of thin gravel deposit on marine clay-silt.

\section{I-307. Kap Wyckoff, N Greenland}

$2580 \pm 150$

Wood from small driftwood log on storm ridge formed of angular limestone rubble $25 \mathrm{ft}$ above sealevel at Kap Wyckoff $\left(82^{\circ} 53^{\prime} \mathrm{N}\right.$ Lat, $24^{\circ} 05^{\prime}$ W Long), Peary Land.

\section{I-308. Danmark Fjord, N Greenland, No. 1}

$4830 \pm 150$

2880 B.c.

Shells, Mya truncata and Hiatella arctica from marine clay-silt terrace $25 \mathrm{ft}$ above sealevel at head of Danmark Fjord $\left(80^{\circ} 31^{\prime} \mathrm{N}\right.$ Lat, $23^{\circ}$ $30^{\prime} \mathrm{W}$ Long). Picked by hand from top 4 in. of clay-silt which is covered by thin veneer of gravel.

\section{I-309. Bronlund Fjord, N Greenland}

$4925 \pm 150$

Shells, Mya truncata, from marine silt and clay, $25 \mathrm{ft}$ above sealevel $\left(82^{\circ} 08^{\prime} \mathrm{N}\right.$ Lat, $29^{\circ} 45^{\prime} \mathrm{W}$ Long), 2 mi NE of Kap Moltke, Br $\phi$ nlund Fjord. Site is ca. $20 \mathrm{mi}$ within limit of former extent of continental ice cap. Sample is from bottom deposits.

\section{I-310. Skagen, N Greenland}

$7900 \pm 200$

5950 B.c.

Shells, Mya truncata and Hiatella arctica imbedded in clay-silt of marine terrace $6 \mathrm{mi} \mathrm{S}\left(83^{\circ} 02^{\prime} \mathrm{N}\right.$ Lat, $25^{\circ} 00^{\prime} \mathrm{W}$ Long) of Skagen, Peary Land. 


\section{I-311. Kфlen, N Greenland}

$8550 \pm 250$

6600 B.C.

Shells, Hiatella arctica from marine clay-silt beds $255 \mathrm{ft}$ above sealevel at K $\phi$ len $\left(82^{\circ} 08^{\prime} \mathrm{N}\right.$ Lat, $29^{\circ} 15^{\prime} \mathrm{W}$ Long), $6 \mathrm{mi} \mathrm{E}$ of Br $\phi$ nlund Fjord. Site is on $\mathrm{N}$ flank of $\mathrm{K} \phi \mathrm{len}$ at highest point on marine clay-silt beds. Comment (W.E.D.): date represents maximum marine transgression in the area and compares well with data of maximum marine transgression in northern Canada (I-215, $8360 \pm 175$, I -179, $8370 \pm 200$, Isotopes II; Craig, 1961).

\section{I-312. Kap Viborg, N Greenland}

$4975 \pm 150$

Wood from small log resting in coarse marine beach gravel $125 \mathrm{ft}$ above sealevel at Kap Viborg ( $80^{\circ} 55^{\prime} \mathrm{N}$ Lat, $23^{\circ} 30^{\prime} \mathrm{W}$ Long) .

\section{I-313. Danmark Fjord, N Greenland, No. 2}

$3375 \pm 150$

Wood from driftwood $\log$ from same site as I-308. Comment (W.E.D.) : date is compatible with other driftwood dates along Danmark Fjord (I-312, I-306, this list), but contrasts slightly with date on marine shells (I-308, $4830 \pm 150)$ from same site.

I-314. Mudder Bugt, N Greenland $>32,000$

Wood (willow?) from top of terminal moraine of continental glacier, $450 \mathrm{ft}$ above sealevel ( $82^{\circ} 28^{\prime} \mathrm{N}$ Lat, $22^{\circ} 45^{\prime} \mathrm{W}$ Long), $8 \mathrm{mi} \mathrm{N}$ of Mudder Bugt, Peary Land. Comment (W.E.D.) : moraine marks maximum Wisconsin advance of continental ice sheet in $\mathrm{N}$ Greenland.

\section{I-371. Ingolfs Fjord, N Greenland}

$7580 \pm 200$ 5630 B.C.

Shells, Mya truncata and Hiatella arctica, from marine clay-silt deposits $220 \mathrm{ft}$ above sealevel $\left(80^{\circ} 27^{\prime} \mathrm{N}\right.$ Lat, $20^{\circ} 45^{\prime} \mathrm{W}$ Long), $3 \mathrm{mi} \mathrm{S}$ of Naesen, Infolfs Fjord.

\section{N Karelia series, Finland}

\section{E. Europe}

Samples from 3 pollen-analytically investigated sediments from $\mathrm{N}$ Karelia, Finland, dated to determine ages of sediments and initial phases of local vegetational history. Coll. and subm. 1963 by Hunnu Hyvärien, Univ. of Helsinki, Helsinki.

I-1173. Inari, Finland, $225 \mathrm{~cm}$

$8550 \pm 300$ 6600 B.C.

Detritus mud from Inari (63 $18^{\prime} \mathrm{N}$ Lat, $30^{\circ} 55^{\prime} \mathrm{E}$ Long), $\mathrm{N}$ Karelia, Finland. Pond bottom sediment from depth of $225 \mathrm{~cm}$ below pond surface. Alt $200 \mathrm{~m}$ above sealevel. Pollen stratigraphic position is Betula maximum. 
I-1172. Inari, Finland, $245 \mathrm{~cm}$

$9540 \pm 300$

7590 B.c.

Silty fine detritus mud from same site as I-1173, but at depth of 245 $\mathrm{cm}$ below pond surface. Underlain by $20 \mathrm{~cm}$ silty mud and $30 \mathrm{~cm}$ silt and sand. Pollen stratigraphic position; NAP rich phase preceding Betula maximum.

\section{Happalahti, N Karelia, Finland, sub-series}

Peat samples from peat bog in Haapalahti, $\mathrm{N}$ Karelia $\left(63^{\circ} 01^{\prime} \mathrm{N}\right.$ Lat, $30^{\circ} 08^{\prime}$ E Long), Finland. Ca. $110 \mathrm{~m}$ above sealevel.

$5025 \pm 220$

I-1177. Haapalahti, Finland, $275 \mathrm{~cm}$

3075 B.C.

Sphagnum-Carex peat from depth of $275 \mathrm{~cm}$ below bog surface. Pollen stratigraphic position: rise of Picea and Pinus after climatic optimum.

I-1176. Haapalahti, Finland, $545 \mathrm{~cm}$

$9155 \pm 300$

Bryales-Carex peat from depth of $545 \mathrm{~cm}$ below bog surface. Pollen stratigraphic position: Pinus maximum.

I-1175. Haapalahti, Finland, $570 \mathrm{~cm}$

$9410 \pm 300$

Bryales-Carex peat from $570 \mathrm{~cm}$ below bog surface. Pollen stratigraphic position: end of Betula maximum.

I-1174. Haapalahti, Finland, $600 \mathrm{~cm}$

$8900 \pm 300$

6950 B.c.

Basal Bryales peat from $600 \mathrm{~cm}$ below surface of bog. Pollen stratigraphic position: beginning of Betula maximum.

\section{I-1178. Koli, Finland}

$9155 \pm 350$

Silty fine-detritus mud from pond sediment at Koli $\left(63^{\circ} 04^{\prime} \mathrm{N}\right.$ Lat, $29^{\circ} 06^{\prime}$ E Long), N Karelia, Finland. From $505 \mathrm{~cm}$ below pond surface at ca. $220 \mathrm{~m}$ above sealevel. Underlain by $5 \mathrm{~cm}$ silty mud and $10 \mathrm{~cm}$ silt and sand. Pollen stratigraphic position: transition from NAP phase to Betula maximum.

General Comment (H.H.): ages for I-1172, I-1173 and I-1178 are in agreement and thus the NAP/Betula phase transition would be more than 9000 B.P. and less than 9500 B.P. Internal inconsistency of dates for I-1174, I-1175, and I-1176 may be due to mixing by water in the raw and partly sand-mixed peat. These latter dates do, however, yield evidence that basal part of the bog, formed during Betula phase, is ca. 9000 yr old, which is in accord with former dates. 


\section{I-680. Ilomantsi, Finland}

Peat from depth of $1.9 \mathrm{~m}$ in bog at Puohtiinsuo, Ilomantsi $\left(62^{\circ} 44^{\prime}\right.$ $\mathrm{N}$ Lat, $31^{\circ} 05^{\prime} \mathrm{E}$ Long), Finland. Bog is at $150 \mathrm{~m}$ alt and sample underlies Sphagnum-Carex peat. Coll. and subm. 1962 by Kimmo Tolonen, Botanical Inst., Univ. of Helsinki, Helsinki. Comment (K.T.) : pollen analysis indicates that sample dates beginning of the spruce (Picea abies) migration in Ilomantsi (Tolonen, 1963).

\section{Kuusamo series, Finland}

Samples from Kuusamo district, Finland to check tentative dating of phases of vegetational development in the area (Vasari, 1962). Coll. 1959 and subm. 1963 by Yrjö Vasari, Dept. of Botany, Univ. of Oulu, Oulu, Finland.

\section{I-774. Meskusjärvi, Finland}

$9150 \pm 300$

Coarse organic mud from Meskusjärvi $\left(66^{\circ} 00^{\prime} \mathrm{N}\right.$ Lat, $28^{\circ} 56^{\prime} \mathrm{E}$ Long). From depth of 230 to $240 \mathrm{~cm}$ in transition zone overlying Carex peat to fine gyttja. Comment (Y.V.) : age is ca. 1000 yr greater than expected, but seems to confirm correlation of the spread of pine forest in this area with late pre-Boreal, early Boreal period (Vasari, 1962).

\section{I-775. Tollakkolampi, Finland, $380 \mathrm{~cm}$}

$8430 \pm 300$

Coarse gyttja and brown peat from Tollakkolampi, Maanselkä $\left(65^{\circ}\right.$ $50^{\prime} \mathrm{N}$ Lat, $29^{\circ} 05^{\prime} \mathrm{E}$ Long). From depth of 380 to $390 \mathrm{~cm}$ at boundary between coarse gyttja and brown moss peat. Comment (Y.V.): date corresponds closely to the supposed age, early Boreal period (Vasari, 1962, 1963; I-774, this series) .

\section{I-777. Tollakkolampi, Finland, $420 \mathrm{~cm}$}

$\mathbf{8 4 3 5} \pm \mathbf{3 0 0}$

Clay gyttja from Tollakkolampi, Maanselkä $\left(65^{\circ} 50^{\prime} \mathrm{N}\right.$ Lat, $29^{\circ} 05^{\prime}$ E Long). From layer of clay gyttja, $10 \mathrm{~cm}$ thick at depth of 420 to $430 \mathrm{~cm}$ between underlying minerogenic sediments and overlying fine gyttja. Comment (Y.V.) : sample was expected to yield date for time of spread of birch forests to this area corresponding to Younger Dryas/pre-Boreal (Vasari, 1963). Age is, however, ca. 1500 yr younger than expected, probably due to contamination with younger material.

\section{I-776. Säynäjälampi, Finland}

$3450 \pm 170$

1500 B.c.

Peat from Säynäjälampi, Teerisuo $\left(66^{\circ} 11^{\prime} \mathrm{N}\right.$ Lat, $28^{\circ} 56^{\prime} \mathrm{E}$ Long), Kuusamo district, Finland. From uppermost $10 \mathrm{~cm}$ of telmatic Sphagnum-Carex-Bryales peat, at depth of 90 to $100 \mathrm{~cm}$, overlain by transgressive gyttja. Coll. 1959 and subm. 1963 by Yrjö Vasari. Comment (Y.V.): sample was expected to confirm correlation of the start of the last phase 
in the local vegetational development with the opening of the Subatlantic period (Vasari, 1962, 1963). Age obtained is ca. $700 \mathrm{yr}$ older than expected.

\section{Woodgrange series, $\mathbf{N}$ Ireland}

Samples of highly humified, dark brown, fine organic detritus from an organic layer underlying marine sand of postglacial age in a raised beach deposit at Woodgrange (54 $19^{\prime} \mathrm{N}$ Lat, $05^{\circ} 47^{\prime} \mathrm{W}$ Long), County Down, N Ireland. Coll. and subm. 1963 by Gurdip Singh, Birbal Sahni Inst. of Paleobotany, Lucknow, India.

\section{I-1198. Woodgrange, N Ireland, No. 1}

$7220 \pm 175$

Top of layer of organic detritus, apparently from Transgression contact.

\section{I-1 199. Woodgrange, $\mathbf{N}$ Ireland, No. 2}

$3125 \pm 150$

Bottom of layer of organic detritus, apparently from Regression contact.

Comment (G.S.) : ages corroborate conclusions obtained from pollen analysis (Singh, 1964; Singh, 1965), and other $\mathrm{C}^{14}$ data (LJ-903, LJ-908, LaJolla IV), that there was massive marine incursion in late Boreal period during which the major part of postglacial relative sealevel rise was completed and that the maximum occurred shortly before 3000 B.P.

\section{F. Africa}

\section{I-1094. Upper Diamond Terrace, Africa}

Barnacles adhering to smooth surface of pothole in schist (discovered during removal of diamantiferous gravels) now ca. $10 \mathrm{~m}$ above sealevel $\left(28^{\circ} 30^{\prime} \mathrm{S}\right.$ Lat, $16^{\circ} 20^{\prime} \mathrm{E}$ Long). Coll. and subm. 1963 by Willard Bascom, Ocean Science and Engineering, Inc., Washington, D. C. Comment (W.B.) : first dating of this raised sea-terrace which extends $30 \mathrm{mi}$ along coast of SW Africa.

\section{I-532. Akasha, Sudan}

$$
\begin{gathered}
11,650 \pm 300 \\
9700 \text { в.c. }
\end{gathered}
$$

Pelecypod shells (Corbicula artini) from Khor Kidingkong $\left(21^{\circ} 12^{\prime}\right.$ $\mathrm{N}$ Lat, $30^{\circ} 41^{\prime}$ E Long), in Akasha district, $200 \mathrm{~m}$ E of Nile, $100 \mathrm{~km} \mathrm{SW}$ of Wadi Halfa, Sudan. Site is $15 \mathrm{~m}$ above Nile flood level, and $195 \mathrm{~m}$ above mean sealevel in soft pale gray Sebilian silt, stratigraphically the younger part, $20 \mathrm{~m}$ below top. There are no associated fossils. Coll. 1961 and subm. 1962 by R. W. Fairbridge, Columbia Univ., New York. Comment (R.W.F.): most shells of sample are articulated, minimizing possibility of reworking or transportation by currents. They occupy a rich horizon in a former backwater of the river in a thick sequence of silts otherwise barren. Since overlying $20 \mathrm{~m}$ of silt is uninterrupted, date re- 
flects youngest high oscillation of the Nile when siltation built the valley to $35 \mathrm{~m}$ above present flood level. Time corresponds to warm (Alleröd) interstadial of Europe and $\mathrm{N}$ America.

\section{G. Brazil}

\section{I-695. Bay of Paranagua, Brazil}

Wood from ilmenite layer under $1.8 \mathrm{~m}$ of old beach deposits at Bay of Paranagua, Parana (25 $\mathrm{S}$ Lat, $48^{\circ} \mathrm{W}$ Long), Brazil. Layer is $0.8 \mathrm{~m}$ above present maximum high tide level. Coll. 1962 by J. J. Bigarella; subm. 1962 by W. R. Hurt, Univ. of Indiana, Bloomington, Indiana. Comment (W.R.H.) : beach deposits overlying specimen may correspond with worldwide rise in sealevel designated the Abrolhos (ca. 2400-2000 B.P.) by Fairbridge (1960).

\section{PHYSICAL GEOGRAPHY SAMPLES \\ A. Canadian North West Territories}

\section{North Baffin Island series}

Samples from various locations on Baffin Island, NW Territories. Coll. and subm. during 1962 and 1965 by members of the Geographical Branch, Dept. of Mines and Tech. Surveys, Ottawa, Canada.

\section{I-1245. Tay Sound}

$4875 \pm 350$

Shells (Pelecypoda) from deltaic beds ca. $127 \mathrm{ft}$ above sealevel on Tay Sound ( $71^{\circ} 56^{\prime} \mathrm{N}$ Lat, $78^{\circ} 35^{\prime} \mathrm{W}$ Long). Coll. 1963 by G. Falconer; subm. 1964 by J. D. Ives. Comment (G.F.): sample alt is $133 \mathrm{ft}$ below local postglacial marine limit.

\section{I-1316. Tay Sound}

$8250 \pm 750$

Shells of Mytilus edulis Linné occurring in situ in deltaic deposit $\left(71^{\circ} 56^{\prime} \mathrm{N}\right.$ Lat, $78^{\circ} 34^{\prime} \mathrm{W}$ Long). Shell-bearing bed exposed at $193 \mathrm{ft}$ above sealevel whereas marine limit is estimated at $260 \mathrm{ft}$. Mytilus edulis was found in association with Macoma balthica (Linné) and Mya sp. but only Mytilus used for dating. Coll. 1963 by G. Falconer; subm by J. T. Andrews.

\section{I-1317. Tay Sound}

$3660 \pm 480$

Marine shells of Macoma balthica (Linné) occurring with Mytilus edulis at $50 \mathrm{ft}$ above sealevel ( $71^{\circ} 52^{\prime} \mathrm{N}$ Lat, $78^{\circ} 23^{\prime} \mathrm{W}$ Long). Coll. by G. Falconer 1965; subm. by J. T. Andrews.

\section{I-724. Tay Sound}

$8350 \pm 300$

6400 B.c.

Pelecypod shells from SW arm of Tay Sound $\left(72^{\circ} 00^{\prime} \mathrm{N}\right.$ Lat, $79^{\circ}$ 15' W Long). From $248 \mathrm{ft}$ above sealevel in raised beach deposits. The 
upper limit of postglacial marine submergence has been identified at $287 \mathrm{ft}$ above sealevel in this locality. Coll. and subm. by G. Falconer. Comment (G.F.): date suggests association with higher sealevels prevailing during latter part of Cockburn I glacial phase (Ives, 1963).

\section{I-1318. Tay Sound}

$4400 \pm 490$

Marine shells Mya sp., probably Mya truncata Linné, found broken in clay beds at $44 \mathrm{ft}$ above sealevel and $6 \mathrm{ft}$ below I-1317 (71 $52^{\prime} \mathrm{N}$ Lat, $78^{\circ} 23^{\prime}$ W Long). Coll. by G. Falconer; subm. by J. T. Andrews.

\section{I-1319. Koluktoo Bay}

$5710 \pm 200$

Marine shells, Mytilus edulis Linné, Astarte montagui var. warha Hancock, Macoma calcarea (Gmelin), Macoma balthica (Linné), Mya truncata (Linné), Hiatella arctica (Linné). Coll. from surface of raised marine shoreline $55 \mathrm{ft}$ above sealevel $\left(80^{\circ} 03^{\prime} \mathrm{N}\right.$ Lat, $81^{\circ} 07^{\prime} \mathrm{W}$ Long). Coll. by G. Falconer; subm. by J. T. Andrews.

\section{I-1246. Koluktoo Bay}

$7930 \pm 300$

Shell fragments from Koluktoo Bay $\left(72^{\circ} 03^{\prime} \mathrm{N}\right.$ Lat, $81^{\circ} 10^{\prime} \mathrm{W}$ Long), Milne Inlet. Coll. from clay deposits within moraine loop ca. 197 ft above sealevel. Coll. 1963 by G. Falconer; subm. 1964 by J. D. Ives. Comment (G.F.): date provides probable minimum date of formation of Cockburn moraine system in N Baffin Island (Ives, 1964).

I-1320. Milne Inlet

$4010 \pm 440$ 2060 B.c.

Marine shells Macoma balthica Mya truncata Hiatella arctica in situ 59 feet above sealevel in sandy deltaic beds $\left(71^{\circ} 53^{\prime} \mathrm{N}\right.$ Lat. $80^{\circ} 55^{\prime}$ $\mathrm{W}$ Long). Shell-bearing layer sloped upwards to surface beach ridges at ca. $68 \mathrm{ft}$. Coll. by G. Falconer; subm. by J. T. Andrews.

\section{I-1315. Aretic Bay}

$9360 \pm 230$

7410 в.c.

Peat from 20-ft thick bed in stream bank on slopes of King George $\mathrm{V}$ Mountain at $150 \mathrm{ft}$ above sealevel ( $73^{\circ} 02^{\prime} \mathrm{N}$ Lat, $85^{\circ} 11^{\prime} \mathrm{W}$ Long). Ref. G. Falconer, J. D. Ives, O. H. L $\phi$ ken, and J. T. Andrews, 1965. Coll. by G. Falconer; subm. by J. T. Andrews.

\section{I-1204. "Tiger" Ice Patch}

$330 \pm 75$

Dead moss (Polytrichum juniperum) from area exposed by ice retreat since summer 1961, on $\mathrm{N}$ Baffin Island $\left(71^{\circ} 20^{\prime} \mathrm{N}\right.$ Lat, $78^{\circ} 50^{\prime} \mathrm{W}$ Long), NW Territory. Coll. 1963 by G. Falconer; subm. by R. Beschel and G. Falconer. Comment (G.F.): recent rapid recession of thin stagnant ice cover in this locality reveals undisturbed patterned ground features and dead moss mats. Sample may date a climatic deterioration 
and significantly more snowy period beginning ca. A.D. 1620. This agrees with Ives' (Ives, 1962) findings based on geomorphic evidence from $\mathrm{N}$ margin of Barnes Ice Cap.

\section{Sam Ford Fiord series}

The following samples were all from the same deposit $\left(70^{\circ} 01^{\prime} \mathrm{N} \mathrm{Lat}\right.$, $71^{\circ} 33^{\prime} \mathrm{W}$ Long) at Sam Ford Fiord, Baffin Island, from sand and silt beds in stratified beach deposit. Coll. and subm. by O. H. L $\phi$ ken.

I-1668. Sam Ford Fiord

$3830 \pm 140$

Shells of Serripes groenlandicus (Bruguiere), Mya truncata and Hiatella arctica. Comment (O.H.L.) : sample dates a relative sealevel 18.5 $\mathrm{m}$ above present sealevel.

\section{I-1669. Sam Ford Fiord}

$4770 \pm 140$

2820 B.c.

Shells of Mya truncata found $435 \mathrm{~m} \mathrm{SW}$ of head of Fiord. Comment (O.H.L.): sample dates a relative sealevel $21.5 \mathrm{~m}$ above present sealevel.

\section{I-1670. Sam Ford Fiord}

$4770 \pm 140$

2820 в.c.

Shells of Mya truncata found $395 \mathrm{~m} \mathrm{SW}$ of head of Fiord. Comment (O.H.L.) : sample dates a relative sealevel $20 \mathrm{~m}$ above present level although there appears to be an unexplained discrepancy between this date and the others in the series.

\section{I-1671. Sam Ford Fiord}

$4270 \pm 140$

Shells of Mya truncata and Hiatella arctica found $455 \mathrm{~m} \mathrm{SW}$ of head of Fiord. Comment (O.H.L.): sample dates a relative sealevel $23.5 \mathrm{~m}$ above present sealevel.

\section{I-1321. Sam Ford Fiord}

$5390 \pm 150$

Shells of Macoma calcarea, Mya sp., and Hiatella arctica from crest of bank ca. $70 \mathrm{ft}$ below marine limit. Ref. Falconer et al., 1965. Coll. by J. D. Ives; subm. by J. T. Andrews. Comment (J.T.A.): date provides a minimum estimate on age of the Cockburn moraines and provides information on the isostatic recovery of the area.

$5560 \pm 250$

\section{I-1243. Walker Arm}

3610 B.C.

Shells from crest of a bank of marine silt on Walker Arm $\left(70^{\circ} 16^{\prime}\right.$ N Lat, $71^{\circ} 43^{\prime}$ W Long) . Coll. 1963 and subm. 1964 by J. D. Ives. Comment (J.D.I.): sample is from $100 \mathrm{ft}$ below marine limit. Age indicates that maximum marine transgression occurred $>5600$ yr B.P. and that outer Cockburn moraines, which terminate far to seaward of locality, must be appreciably older than 5600 в.P. 


\section{I-1553. Sam Ford Fiord}

$7500 \pm 200$

5550 в.C.

Shells of Macoma sp. found on E side of Sam Ford Fiord $\left(70^{\circ} 13^{\prime}\right.$ $\mathrm{N}$ Lat, $71^{\circ} 18^{\prime} \mathrm{W}$ Long), on a delta associated with terminal position of outlet glacier. Coll. and subm. by O. H. L $\phi$ ken. Comment (O.H.L.): date gives maximum age of adjacent terminal moraine.

\section{I-1556. Sam Ford Fiord}

Shells of Macoma sp. from a site $2.5 \mathrm{~km} \mathrm{~W}$ of head of Fiord in clay on edge of a fluvial deposit. Coll. and subm. by O. H. L $\phi$ ken. Comment (O.H.L.) : sample gives minimum date for deglaciation of the inner part of the Fiord.

\section{Inugsuin Fiord series}

Shells from sand and silt beds in stratified beach deposit $\left(69^{\circ} 37^{\prime} \mathrm{N}\right.$ Lat, $70^{\circ} 01^{\prime}$ W Long). Coll. by O. H. L $\phi$ ken; subm. by J. D. Ives. Ref. L $\phi$ ken, O. H., 1965.

\section{I-1554. Inugsuin Fiord}

$7030 \pm 190$

Shells of Chlamys islandicus (Muller) Clinocardium ciliatum (Fabricius), Mytilus edulis, Mya truncata, Hiatella arctica found $920 \mathrm{~m} \mathrm{~S}$ of head of fiord. Comment (O.H.L.): date gives age of relative sealevel more than $44.5 \mathrm{~m}$ above present sealevel.

\section{I-1555. Inugsuin Fiord}

$2800 \pm 140$ 850 B.C.

Shells of Mytilus edulis, Hiatella arctica, Macoma balthica from $250 \mathrm{~m} \mathrm{~S}$ of head of fiord. Dating relative sealevel $8.0 \mathrm{~m}$ above present sealevel (O.H.L.).

\section{I-1596. Inugsuin Fiord}

$6150 \pm 170$

4200 B.c.

Shells of Mytilus edulis from $830 \mathrm{~m} \mathrm{~S}$ of head of fiord dating a relative sealevel $37.0 \mathrm{~m}$ above present sealevel (O.H.L.).

\section{I-1597. Inugsuin Fiord}

$4090 \pm 150$

Shells of Mytilus edulis, Mya truncata, Macoma balthica, Hiatella arctica from $480 \mathrm{~m} \mathrm{~S}$ of head of fiord dating sealevel $1915 \mathrm{~m}$ above present sealevel (O.H.L.).

\section{I-1598. Inugsuin Fiord}

Shells of Clinocardium ciliatum, Hiatella arctica, Mya truncata from $925 \mathrm{~m} \mathrm{~S}$ of head of fiord and dating a relative sealevel $44.5 \mathrm{~m}$ above present level (O.H.L.). 


\section{I-1599. Inugsuin Fiord}

Shells of Macoma balthica, Hiatella arctica, and Mya truncata from $320 \mathrm{~m} \mathrm{~S}$ of head of fiord dating a relative sealevel $9.0 \mathrm{~m}$ above present level (O.H.L.).

\section{I-1600. Inugsuin Fiord}

Shells of Mya pseudoarenaria (Schlesh.) and Mya truncata found 380 $\mathrm{m} \mathrm{S}$ of head of fiord and dating a relative sealevel $14.5 \mathrm{~m}$ above present level (O.H.L.).

\section{I-1601. Inugsuin Fiord}

$3530 \pm 130$

Shells of Mytilus edulis, Mya truncata, Macoma balthica, Mya pseudoarenaria and Hiatella arctica from $420 \mathrm{~m}$ above head of fiord and dating a relative sealevel of more than $12.8 \mathrm{~m}$ above the present. (O.H.L.).

\section{I-1602. Inugsuin Fiord}

$7900 \pm 210$

Shells of Chlamys islandicus from head of fiord $\left(69^{\circ} 38^{\prime} \mathrm{N}\right.$ Lat, $70^{\circ}$ $02^{\prime}$ W Long) at alt of $32 \mathrm{~m}$ above sealevel, from folded bed of sand and silt. Coll. by D. M. Barnett; subm. by O. H. L $\phi$ ken. Comment (O.H.L.): sample dates the minimum age.

\section{I-1672. Inugsuin Fiord}

$7080 \pm 170$

Shells of Pelecypoda and Gastropoda from head of fiord $\left(69^{\circ} 38^{\prime} \mathrm{N}\right.$ Lat, $70^{\circ} 02^{\prime}$ W Long). Coll. and subm. by O. H. L $\phi$ ken. Coll. in sand bed above I-1602. The difference in age between the two samples gives an indication of deposition time for the intervening sediment.

\section{I-1673.}

$7970 \pm 340$

Marine mollusc shells from head of fiord $\left(69^{\circ} 38^{\prime} \mathrm{N}\right.$ Lat, $70^{\circ} 02^{\prime} \mathrm{W}$ Long). Sample found in contorted silt bed. Coll by D. M. Barnett; subm. by O. H. L $\phi$ ken. Comment (O.H.L.): coll. in same deposit as I-1602 but stratigraphically slightly above it.

\section{McBeth Fiord series}

\section{I-1603. Thanes Lake}

$$
170 \pm 105
$$

Stem and root of Arctic Willow (Salix herbacea) $\left(69^{\circ} 4 \mathrm{l}^{\prime} \mathrm{N}\right.$ Lat, $68^{\circ} 44^{\prime}$ W Long). Coll. by D. A. Harrison; subm. by O. H. L $\phi$ ken. The material was covered by lacustrine deposit from an ice dammed lake for which it gives a maximum age. 
I-1674. Cawdor Glacier

Mosses and lichens collected from rocks that were covered by a glacier until 5-7 yr ago. Collected to see if vegetation could survive a readvance of a glacier. Result inconclusive (O.H.L.).

\section{West Coast series}

\section{I-1242. Felside Lake}

$19,000 \pm 1000$

17,050 B.c.

Shells, (Pelecypoda, Cirripedia) from S end of Felside Lake, Steensby Inlet $\left(70^{\circ} 03^{\prime} \mathrm{N}\right.$ Lat, $77^{\circ} 30^{\prime} \mathrm{W}$ Long). Sample from frost boils at elev of $115 \pm 7 \mathrm{~m}$ above sealevel or ca. $25 \mathrm{~m}$ above marine limit. Coll. 1963 by D. A. Harrison; subm. 1964 by J. D. Ives. Comment (J.T.A.): shell fragments are from surface of a calcareous till containing dolomite fragments from an area $\mathrm{W}$ of Felside Lake. Both dolomite fragments and shells were probably transported from the $\mathrm{W}$ by ice. Date possibly indicates a period of open water in Foxe Basin at ca. 19,000 B.P. Date compares with I-725, 17,800 \pm 500 (unpub.) and I-1314, 18,700 \pm 1200 (unpub.) from a locality $45 \mathrm{mi} \mathrm{N}$ of the head of Steensby Inlet.

\section{I-725. Foxe Basin}

$$
\begin{aligned}
& \mathbf{1 7 , 8 0 0} \pm \mathbf{5 0 0} \\
& \mathbf{1 5 , 8 5 0} \text { в.c. } \\
& \mathbf{1 8 , 7 0 0} \pm \mathbf{1 2 0 0} \\
& 17,750 \text { в.C. }
\end{aligned}
$$

\section{I-1314. Foxe Basin}

Shells of Mya sp. and Astarte sp. coll. by G. Falconer $45 \mathrm{mi} \mathrm{N}$ of head of Steensby Inlet ( $71^{\circ} 08^{\prime} \mathrm{N}$ Lat, $78^{\circ} 38^{\prime} \mathrm{W}$ Long). Ref. J. T. Andrews and G. Falconer (in preparation). Comment (G.F.): site is $170 \mathrm{ft}$ above limit of postglacial marine incursion on E coast of Steensby Inlet. Two dates were obtained from a single sample. The first (I-725) was obtained after removal of the outer 10 percent, the second (I-1314) after removal of the outer 50 percent. There is good agreement between the dates obtained from I-725 and I-1314 with I-1242 (19,000 $\pm 1,000)$ coll. by J. T. Andrews at a locality further south, and it is possible that the molluscs lived in open Foxe Basin sea ca. 19,000 yr ago.

\section{Isortoq Detrital Bed series}

$$
24,600 \pm 500
$$

I-731. Isortoq River

$$
22,650 \text { в.c. }
$$

Woody peat from bank of Isortoq River $\left(75^{\circ} 05^{\prime} \mathrm{N}\right.$ Lat, $70^{\circ} 16^{\prime} \mathrm{W}$ Long), $16 \mathrm{mi} \mathrm{W}$ of present margin of Barnes Ice Cap. Site is a river bank exposure of $7 \mathrm{~m}$ of contorted peat; sample from $4 \mathrm{~m}$ above river level. Coll. 1962 and subm. 1963 by J. T. Andrews. Comment (J.T.A.): date need not represent maximum age of deposit because of inclination of bedding. Alder and dwarf birch remains suggest a slightly warmer climate than today. Taken in conjunction with I-839 there is a strong implication that during the period 24,000 to 30,000 B.P., the large pro- 
portion of N-central Baffin Island was ice-free or at least carried less glacier ice than today (Andrews, 1963; Ives, 1964).

\section{I-1233. Isortoq River}

$14,400 \pm 400$

12,450 в.C.

Peat from horizontal plant teaming beds truncating folded peat beds at approx. $690 \mathrm{ft}$ above sealevel $\left(75^{\circ} 05^{\prime} \mathrm{N} \mathrm{Lat}, 70^{\circ} 16^{\prime} \mathrm{W}\right.$ Long). Coll. and subm. by J. T. Andrews, 1963.

\section{I-1234. Isortoq River}

$>35,000$

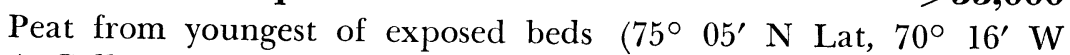
Long). Coll. and subm. 1963 by J. T. Andrews.

\section{I-1235. Isortoq River}

Peat from under horizontal river sand, the oldest peat exposed $\left(75^{\circ}\right.$ $05^{\prime} \mathrm{N}$ Lat, $70^{\circ} 16^{\prime} \mathrm{W}$ Long). Coll. and subm. by J. T. Andrews, 1963.

\section{I-1244. Isortoq Fiord}

$5070 \pm 450$

Shells from frost boil on gently sloping clay flat $140 \mathrm{ft}$ above sealevel at Isortoq Fiord $\left(69^{\circ} 56^{\prime} \mathrm{N}\right.$ Lat, $76^{\circ} 54^{\prime} \mathrm{W}$ Long). Coll. and subm. 1963 by J. D. Ives. Comment (J.D.I.): coll. $150 \mathrm{ft}$ below marine limit of this vicinity; provides evidence of area's progressive isostatic recovery and minimum date for withdrawal eastwards of Isortoq Valley glacier.

\section{I-1247. Isortoq Fiord}

$3550 \pm 200$

Leaves and twigs of willow and mosses from Delta Valley, Isortoq Fiord ( $69^{\circ} 56^{\prime} \mathrm{N}$ Lat, $77^{\circ} 02^{\prime} \mathrm{W}$ Long). From a sporadic layer between coarse and fine sands of a delta at $17.93 \mathrm{~m}$ above sealevel. Coll. 1963 by D. A. Harrison; subm. 1964 by J. T. Andrews. Comment (J.D.I.): sampled from same vicinity as I-1244 and provides further data on postglacial relationship between land and sea levels.

\section{I-839. Isortoq River}

$30,000 \pm 1200$

Leafy peat, partially carbonized, from same site as I-731, but immediately above river level. Coll. 1962 and subm. 1963 by J. T. Andrews. Comment: see I-731.

\section{I-1240. Lewis Glacier}

Root or stem (Salix sp.) incorporated into ground moraine and uncovered, after 1948, by Lewis Glacier ( $70^{\circ} 26^{\prime} \mathrm{N}$ Lat, $74^{\circ} 44^{\prime} \mathrm{W}$ Long), NW margin of Barnes Ice Cap. Sample alt is $1300 \mathrm{ft}$ above sealevel. Coll. by M. Church; subm. 1963 by J. T. Andrews. Comment (J.T.A.): date is surprisingly old in view of appearance of sample which had been assumed to date from the period prior to the 17 th century advance of the Lewis Glacier. Date compares, however, to dates on plant fragments from Flitaway Lake (I-1241, this list), and Isortoq Valley (I-1234, I-1235, this 
list). These samples contained plant remnants indicative of a warmer climate than exists today and may be evidence for an interglacial period.

\section{I-1241. Flitaway Lake}

Organic plant remains including scales of Betula nana from Flitaway lake $\left(70^{\circ} 29^{\prime} \mathrm{N}\right.$ Lat, $74^{\circ} 40^{\prime} \mathrm{W}$ Long). Plant fragments occurred as a loosely compact cover over an ice-covered mound $1 \mathrm{~km}$ from present NW margin of Barnes Ice Cap. Remains were also incorporated into till layer above ice core. Coll. and subm. 1963 by J. T. Andrews. Comment (J.T.A.): date for this site may be compared to similar dates on plant remains from other localities in N-central Baffin Island (cf. I-1240, I-1234, I-1235, this list). Pollen and macro-fossil studies by J. Terasmae of Geol. Survey of Canada, and P. J. Webber of Queens Univ., indicate an assemblage of plants not found in the area today, but which do occur further S. Deposit may be tentatively referred to as from an interglacial period.

\section{I-1238. Duart Bay}

$5070 \pm 200$

Shells coll. from bedded sands of a delta $54 \mathrm{ft}$ above sealevel, Duart Bay $\left(71^{\circ} 21^{\prime} \mathrm{N}\right.$ Lat, $72^{\circ} 54^{\prime} \mathrm{W}$ Long), Dexterity Fiord, Bruce Mts. Coll. by D. A. Harrison; subm. 1964 by J. D. Ives. Comment (J.T.A.): date adds to small number of dates available for the $\mathrm{E}$ coast of Baffin Island (cf. I-1243). The dates provide minimum dates for the withdrawal of main outlet glaciers from the fiords, and give indications of the postglacial relationship between land and sealevels (Harrison, 1964).

\section{B. Labrador, Newfoundland, Canada}

\section{Churchill River (formerly Hamilton River) series, Labrador}

Peat samples from along the Churchill River, Labrador. Coll. 1962 by A. Morrison, Geog. Dept., McGill Univ., Montreal; subm. 1963 by J. D. Ives.

\section{I-728. Sona Lake}

Sandy peat from bog in a kettle on isthmus between Sona Lake and Whitefish Lake $\left(53^{\circ} 35^{\prime} \mathrm{N}\right.$ Lat, $63^{\circ} 57^{\prime} \mathrm{W}$ Long), Labrador. From lowest predominantly organic material from deepest part of the bog, at depth of 260 to $270 \mathrm{~cm}$ below surface. Overlain by peat, underlain by silty sand to a depth of $300 \mathrm{~cm}$. Comment (A.M.): age based on single count only, but checks well with I-880 and I-853, this series.

\section{I-853. Churchill Falls (formerly Grand Falls)}

Silty peat and woody fragments from bog on SW rim of Churchill Falls (53 $36^{\prime} \mathrm{N}$ Lat, $64^{\circ} 19^{\prime} \mathrm{W}$ Long), of Churchill River, Labrador. Obtained by Hiller corer from 370 to $380 \mathrm{~cm}$ below surface of bog lo- 
cated in a kettle apparently truncated by retreat of the Falls. Sample was lowest predominantly organic material in core, and probably lowest in the bog. Overlain by peat and underlain by silt to depth of $427 \mathrm{~cm}$.

\section{I-880. Churchill Falls, Labrador, N}

Peat from bog in a kettle close to NE bank of Churchill River, 1/2 mi N (53 $36^{\prime} \mathrm{N}$ Lat, 64 $19^{\prime} \mathrm{W}$ Long) of Churchill Falls, Labrador. Obtained by Hiller corer from 220 to $230 \mathrm{~cm}$ below surface. Lowest predominantly organic material in core, and probably lowest in the bog. Overlain by peat, underlain by silt to depth of $>305 \mathrm{~cm}$. Corer did not reach bottom of basin of deposition. Comment (A.M.): based on three dates of the series, allowing time for deposition of the small layers of silt below samples and for formation of the first peat, best estimate of date of deglaciation of Churchill Falls area is ca. 5750 B.P. (Morrison, 1963). Dates compare with those obtained by Grayson (Grayson, 1956) on SM354, SM-355, SM-356 (Socony Mobil I).

\section{I-1322. Eclipse Channel}

$8190 \pm 710$

Shells of Mya truncata from silty clay $\left(59^{\circ} 48^{\prime} \mathrm{N}\right.$ Lat, $64^{\circ} 16^{\prime} \mathrm{W}$ Long). Comment (O.H.L.): sample was collected immediately below the SL4 strandline and was expected to give a minimum age for this. The age is unexpectedly high and redeposition of the shells is suspected, particularly as shell was mainly fragments.

\section{Other Provinces}

$585 \pm 205$

\section{I-1393. South Saskatchewan River}

A.D. 1365

Carbonized wood from halfway up an 8-m cutback along South Saskatchewan River (50 $57^{\prime} \mathrm{N}$ Lat, $108^{\circ} 41^{\prime} \mathrm{W}$ Long), in conjunction with numerous bison bones. Coll. 1964 by D. A. St. Onge; subm. by J. T. Andrews. Comment (J.T.A.): purpose of date was to determine recent history of South Saskatchewan River. Date implies that river has for the past $500 \mathrm{yr}$ been in a state of dynamic equilibrium.

\section{I-1127. Kingston, Ontario}

$>18,000$

Shells from W side Division Street (44 $16^{\prime} \mathrm{N}$ Lat, $76^{\circ} 30^{\prime} \mathrm{W}$ Long), Kingston, Ontario. Found in silty clay, $2 \mathrm{~m}$ below crest of "small moraine." Coll. and subm. 1963 by O. H. Lфken, Queens Univ., Dept. of Geog., Kingston, Ontario. Comment (O.H.L.): the small moraines were formed during a late readvance of the ice sheet in the region. Since shells were imbedded in a moraine, they must predate the moraine, thus giving a maximum age for the readvance (L $\phi \mathrm{ken}, 1964)$.

Marine molluscs, (Mya truncata, Hiatella arctica) from $\mathrm{W}$ side Deception Bay $\left(62^{\circ} 09^{\prime} \mathrm{N}\right.$ Lat, $72^{\circ} 45^{\prime} \mathrm{W}$ Long), Quebec. Coll. from raised 
marine beach material $281 \mathrm{ft}$ above sealevel in area where marine limit is ca. $400 \mathrm{ft}$. Coll. 1961 by B. Matthews, McGill Univ., Montreal; subm. 1962 by J. D. Ives, Geog. Branch, Dept. of Mines and Tech. Surveys, Ottawa. Comment (J.D.I.): age is greatest obtained for marine molluscs from raised shore features in the Hudson Bay-Hudson Straits-Foxe Basin area. It indicates open water conditions at ca. the time of Valders Readvance of more southern lats. Marine level is $>200 \mathrm{ft}$ above height of this sample and higher samples may yield older dates.

\section{ARCHAEOLOGIC SAMPLES}

\section{A. United States}

\section{Iron Gate Reservoir series, California}

Charcoal and charred wood from House-Pit 4, near $S$ bank of Klamath River, ca. $200 \mathrm{ft}$ upstream from Jenny Creek $\left(41^{\circ} 58^{\prime} \mathrm{N}\right.$ Lat, $122^{\circ} 22^{\prime} \mathrm{W}$ Long), California. Site is village on small terrace in an area now flooded by Iron Gate Reservoir of Pacific Power and Light Co. A succession of houses had been built in the pit originally dug for the first house (Cressman et al., 1956). Floors are numbered from the bottom in order of use. Coll. 1960 by D. L. Cole; subm. 1961 by L. S. Cressman, Univ. of Oregon, Eugene.

\section{I-230. Iron Gate, Floors 2, 3}

$510 \pm 75$

Charred wood from fill varying from 5 to $10 \mathrm{~cm}$ deep between Floors 2 and 3.

\section{I-231. Iron Gate, Floor 1}

$400 \pm 75$

Charred wood from beam on Floor 1, earliest in series.

General Comment (L.S.C.): difference between levels between the two samples is very small $(5$ to $10 \mathrm{~cm})$, and fill could have accumulated quickly. Difference in dates is not statistically significant, and results do not represent a reversal of stratigraphy.

\section{I-502. Salt Caves Dam, California}

$1280 \pm 125$

Charcoal from midden associated with village at Salt Caves Dam ( $42^{\circ} 01^{\prime} \mathrm{N}$ Lat, $122^{\circ} 10^{\prime} \mathrm{W}$ Long), in Klamath River Canyon, ca. $12 \mathrm{mi}$ from Dorris, California. Site has three geological strata reading from bottom to top: I) large well-rounded river cobbles larger than ferry transported by river now; II) cemented gravels, less rounded and smaller than in I; III) midden. Artifacts tentatively grouped into three levels. Sample is from near bottom of Geological Stratum III, Cultural Level 1 (Cressman, 1942). Coll. 1961 by John Wells; subm. 1962 by L. S. Cressman. 
I-681. Leslie mound, W Virginia

$2250 \pm 150$

300 B.C.

Charred wood from Leslie mound, $4 \mathrm{mi}$ upstream $\left(38^{\circ} 30^{\prime} \mathrm{N}\right.$ Lat, $81^{\circ} 51^{\prime}$ W Long) from Winfield, W Virginia, on SW bank of Kanawha River. From postmould under mound which also contained an Armstrong Plain pottery sherd. Coll. and subm. 1962 by E. V. McMichael, W Virginia Geol. Survey. Comment (E.V.McM.): expected to date Hopewellian Armstrong culture of central W Virginia, but appears to be too early. Proper assessment must, however, await additional dates on this culture (McMichael and Mairs, 1963).

\section{B. Sudan}

\section{I-530. Khor Khageras, Sudan}

$7300 \pm 350$

$\mathbf{5 3 5 0}$ в.c.

Charcoal from $200 \mathrm{~m}$ NE of junction of Khor Khageras and Nile, between Ukma and Akasha $\left(21^{\circ} 07^{\prime} \mathrm{N}\right.$ Lat, $30^{\circ} 42^{\prime} \mathrm{E}$ Long), Sudan. From lenticular depression (fireplace?), $40 \mathrm{~cm}$ in diam, $60 \mathrm{~cm}$ below sürface in a sequence of Mid-Holocene silts, $13 \mathrm{~m}$ above present high flood level of Nile. Coll. 1961 and subm. 1962 by R. W. Fairbridge. Comment (R.W.F.): silts containing sample clearly abut the middle and older (Sebilian-Wisconsin) silts. Date compares with M-804, $8260 \pm 400$ (Michigan V) on shells in Jebel Maktub pothole $100 \mathrm{~km} \mathrm{~N}$ of Akasha. Fireplace clearly shows a seasonal emergence of the flood-deposited silts. No diagnostic artifacts were discovered during excavation but terrace surface is strewn with microlithic tools of broadly Mesolithic character.

\section{Wadi Halfa series, Sudan}

Charcoal and charred grain samples from two sites $\mathrm{W}$ of Nile River (21 $57^{\prime} \mathrm{N}$ Lat, $31^{\circ} 20^{\prime} \mathrm{E}$ Long), $\mathrm{N}$ of main mosque in Wadi Halfa, Northern Province, Republic of Sudan. Coll. 1962 and 1963 by J. B. Wheat, Duane Quiatt, Minor Van Arsdale; subm. 1963 by G. W. Hewes, Univ. of Colorado, Boulder, Colorado.

\section{I-863. Wadi Halfa, Sudan, Site 6B27, No. A 16,150}

Wood (?) charcoal from exposed face of ancient soil horizon, an erosional remnant of laminated silt deposited by ancient Nile, at Site 6D27, $1100 \mathrm{~m} \mathrm{~W}$ of Nile River and $2.4 \mathrm{~km} \mathrm{~N}$ of main mosque in Wadi Halfa. Site is in Western Desert, $142 \mathrm{~m}$ above mean sealevel and $20 \mathrm{~m}$ above present mean level of Nile. Soil is extremely hard, has traces of hearth lenses, scattered fossil mammal bone fragments and flint chips. Fossil bones of large extinct bovids present. Charcoal apparently washed into place. Comment (G.W.H.): carbon content of sample was low and possibly subject to contamination with older material. Associated lithic artifacts, mainly flint and chert flakes apparently belonging to EpiLevalloisian (Upper Palaeolithic) tradition, would be expected to fit 
this 16,000 B.c. date (Butzer, 1962). Age is closer to expectations than I-864, from same site (Hewes, 1963).

\section{I-866. Wadi Halfa, Sudan, Site 6G9, No. D A.D. 105}

$1845 \pm 190$

Wood charcoal from roofing poles which had fallen on to fill of sand and ash above room floor. Comment (G.W.H.): slightly younger date on this sample is reasonable if roofing material had been replaced during life of structure. This practice is still followed in modern Nubia. See also comments on I-865.

\section{I-867. Wadi Halfa, Sudan, Site 6G9, No. E}

Charcoal from ash deposit in a in a line of burned rubble running $\mathrm{N}$ to $S$ in Room 20 at same site as I-865, but on $\mathbf{E}$ side of principal rooms. Rubble is ca. $50 \mathrm{~cm}$ from present sand surface and contained mudbricks and a few sherds identified as of Pharaonic type (Hewes, 1963). Comment (G.W.H.): date seems to confirm supposition that the feature antedated by some time the main part of the structure. Sherds and other finds fall into Napatan period, prior to removal of the Kushite capital from Napata to Meroe. Date in conjunction with other evidence, suggests that Site 6G9 had an earlier transitory occupancy, of which clearcut building remains had disappeared (or were used for later construction) by the time main part of site was used as a habitation.

\section{I-864. Wadi Halfa, Sudan, Site 6B27, No. B $6150 \pm 300$}

Charcoal from Hearth A, at same site as I-863. Comment (G.W.H.): date seems too recent for nature of associated artifacts. Pottery was in use in area by 4200 B.c., but no ceramic remains whatever were found at this, or adjacent camp sites (Hewes, 1963). Sample was perhaps contaminated by rootlets during the Subpluvial (Butzer, 1962).

\section{I-865. Wadi Halfa, Sudan, Site 6G9, No. C $2100 \pm 22$

$$
150 \text { B.c. }
$$

Charcoal from fire lens beneath stone house wall in main section of dwelling area in Gezira Dabarosa village, $600 \mathrm{~m} \mathrm{~W}$ of Nile River, 1100 $\mathrm{m} \mathrm{N}$ of main mosque in Wadi Halfa. Hearth presumably antedates laying of the rough mortar-less stone wall Nordström, 1962). Comment (G.W.H.): this date, along with I-866 and I-868 from same site, agrees with estimates based on pottery and other indications that Site 6G9 was occupied for a brief period in earlier part of Meroitic period (Nordström, 1962; Hewes, 1963).

\section{I-868. Wadi Halfa, Sudan, Site 6G9, No. F}

Carbonized grain (wheat?) from Room 15 at same site as I-866. Grain was spread fairly widely at floor level between Floors 1 and 2 (Hewes, 1963). Comment: see I-865. 


\section{Veii series, Italy}

$$
\text { C. Italy }
$$

Charcoal from banks of streams N $\left(42^{\circ} \mathrm{N}\right.$ Lat, $12^{\circ} 30^{\prime} \mathrm{E}$ Long) of Rome, Italy. Obtained during archaeological investigations in vicinity of Etruscan city of Veii. Coll. and subm. 1962 by Sheldon Judson, Princeton Univ., Princeton, New Jersey.

\section{I-881. Valchetta, Italy, No. 1}

$$
1140 \pm 160
$$

\section{A.D. 810}

Charcoal from zone marking destruction of a late Roman bath and related structures on banks of La Valchetta stream, $15 \mathrm{mi} \mathrm{N}$ of Rome. Comment (S.J.): date is somewhat young, but in general agrees with geological and archaeological evidence (Judson, 1963).

\section{I-882. Crescenza, Italy, No. 11}

$1400 \pm 100$

From banks of La Crescenza stream $10 \mathrm{mi} \mathrm{N}$ of Rome at point where ancient road from Rome to Veii crosses the stream. Comment (S.J.): date is supported by archaeologic evidence from rubble zone which provides an age of post 3rd century A.D. (Judson, 1963).

\section{I-883. Crescenza, Italy, No. 9}

$3648 \pm 250$

From same site as I-882, but from level dated by archaeological evidence as from ca. A.D. 50. Comment (S.J.): date differs greatly from expected age. No explanation for anomaly is known and age based upon cultural and geologic evidence seems acceptable (Judson, 1963).

\section{South Pacific}

\section{Mangareva series, French Polynesia}

Charcoal samples obtained during archaeological excavations on Mangareva (23 $08^{\prime}$ S Lat, $134^{\circ} 56^{\prime} \mathrm{W}$ Long). Coll. 1959 by R. C. Green; subm. 1960 by H. L. Shapiro, Am. Mus. of Nat. Hist., New York.

\section{I-193. Site GA-1, Mangareva}

From Square B-1, Cultural Layer C, at Te Ana Puta Rua, Aukena, in a charcoal lens just above underlying sterile sand floor of cave. Comment (R.C.G.): dates time of initial occupation of cave and from comparisons with artifacts recovered agrees with sequence established by other dates in series.

\section{I-191. Kitchen Cave, Layer G, Mangareva}

From fire pit in Square Z-2, Cultural Layer G, in Kitchen Cave, Kamaka, Site GK-1. Comment (R.C.G.): Square Z-2 has best stratified sequence and was adopted as standard of sequence for other squares. Dates in sequence seem to agree with cultural evidence. 
I-190. Kitchen Cave, Layer J, Mangareva

From firepit in sterile floor in Square A-1, Cultural Layer J, Kitchen Cave, Kamaka. Comment (R.C.G.): dates earliest occupation of site.

I-192. Sancho's Cave, Mangareva

From cultural Layer C, directly under a stone religious structure at Sancho's Cave, Kamaka, Site GK-3. Comment: sample was expected to date artifacts from beneath pavement of structure which dates to just before European contact ca. 150 B.P. Validity of the age is uncertain, but should not be far off.

\section{Moorea series, French Polynesia}

Charcoal samples collected during achaeological investigations on Moorea $\left(17^{\circ} 30^{\prime} \mathrm{S}\right.$ Lat, $149^{\circ} 50^{\prime} \mathrm{W}$ Long), in Society Islands. Stratigraphy at most sites along coast has been obliterated or obscured by burrowing land crabs. Coll. 1960 by R. C. Green; subm. 1960 by H. L. Shapiro.

\section{I-204. Amehiti, Moorea}

From small oven lying under stone curbing of $\mathrm{W}$ wall of large round ended assembly house at Site ScMo-4, Amehiti. Comment (R.G.G.): oven correlates with a set of earlier post-holes on storage pits from a similar house on same site as that now marked by stone curbing and provides date for earlier house.

\section{I-188. Te Ama Ama, Moorea}

$760 \pm 80$

From oven dug into sand at base of overlying cultural deposits and ca. 37 in. below surface at Site ScMf-4, Te Ama Ama, Papetoai. Associated with other cultural deposits including an adze, shell chisels, and a coconut grater. Overlying deposits are disturbed by burrowing land crabs, but oven and sample level appears intact. Comment (R.C.G.): sample level was below sealevel and immersed in brackish water. Date agrees with cultural evidence.

\section{I-189. Vai Ohu'a, Moorea}

$540 \pm 75$

From small oven at base of cultural deposits, ca. 41 in. below site is one of few undisturbed by land crabs; cultural stratification can be determined. This date and I-188 are from the only two sites where an indication of age of artifacts associated with cultural layers may be given.

\section{Chilca series, Peru}

E. Peru

Samples from several sites along the Chilca, an intermittent river on central coast $\left(12^{\circ} 26^{\prime} \mathrm{S}\right.$ Lat, $76^{\circ} 46^{\prime} \mathrm{W}$ Long) of Peru. Coll. and 
subm. 1963 to 1964 by Frederic Engel, Universidad Nacional Agraria, Lima, Peru (Engel, 1964).

\section{I-835. Village 1, v-806, Peru}

$5650 \pm 220$

3700 B.c.

Charcoal from bottom strata at Village $1\left(12^{\circ} 29^{\prime} 48^{\prime \prime}\right.$ S. Lat, $76^{\circ}$ $44^{\prime} 48^{\prime \prime}$ W Long). Comment (F.E.) : date fits well for early pre-cotton, preceramic phase of the period on central coast of Peru (cf. NZ-1053, $5700 \pm 136)$.

I-811. Village 1, v-800, Peru

$5250 \pm 220$

Charcoal from Village 1, on left bank of the Chilca, ca. $3 \mathrm{~km} \mathrm{E}$ of Pacific Ocean. Coll. from Level 2A which contains some pottery fragments. Comment (F.E.) : age is inconsistent with stratigraphic interpretation. Stratigraphy may have been disturbed by the Chavinoid who resettled the site or by their burning of earlier wood posts. I-812, $2420 \pm$ 175, from same level yields expected age for Chavin reoccupation. Other samples from same level yield ages consistent with I-811 (cf. I-818, I-800, I-817, I-813). A disturbed stratigraphy, therefore, seems likely.

I-818. Village 1, v-798, Peru

$4525 \pm 220$

Charcoal from Level 2 at Village 1. Level contains some pottery fragments. Comment (F.E.) : age inconsistent with stratigraphic interpretations. See comments for I-811.

\section{I-817. Village 1, v-795, Peru}

$5250 \pm 220$

3300 B.c.

Charcoal from Level 2 at Village 1. Comment (F.E.): age not consistent with stratigraphic interpretations. See comments for I-811.

I-813. Village 1, v-794, Peru

$5650 \pm 190$

Charcoal from Level 2C which contains some pottery fragments. Comment (F.E.): age inconsistent with stratigraphic interpretation, but fairly consistent with other samples from similar levels. See comments for I-811.

I-815. Village 1, v-793, Peru

$5025 \pm 200$

Charcoal from Level 2 which contains some pottery fragments. Comment (F.E.) : see I-811.

I-746. Village 1, v-778, Peru

$4850 \pm 170$

2900 B.c.

Charcoal from Level 2B in Village 1. Comment (F.E.): age not consistent with stratigraphic estimates. See I-811. 


\section{I-745. Village 1, v-777, Peru}

3025 B.c.

Reed mat wrapping funeral bundle in Grave 42 in W cemetery of middle level of Village 1. Comment (F.E.): gives age of cemetery belonging to intermediate period of village which lasted to ca. 4500 B.P. See also I-814.

\section{I-814. Village 1, v-796, Peru}

$4950 \pm 220$

Charcoal from middle level of Village 1. Comment (F.E.): date sets age for middle level of village and is consistent with age for I-745 from equivalent level.

\section{I-812. Village 1, v-797, Peru}

$$
2420 \pm 175
$$

470 в.c.

Charcoal from Level 2A in Village 1. Level contains Chavinoid pottery. Comment (F.E.) : age is consistent with expected age for Chavinoid level.

\section{I-892. Village 1, v-829, Peru}

$$
\mathbf{5 4 1 0} \pm \mathbf{2 7 5}
$$

Charcoal from deepest natural level encountered during a stratigraphic control cut at Village 1. Comment (F.E.): age is in correct range and compares with other dates from equivalent levels (NZ-1053, $5700 \pm$ 136 ; I-835, $5650 \pm 220 ; \mathrm{I}-813,5650 \pm 190$ ) .

\section{I-816. Village 1, v-799, Peru}

$4500 \pm 190$ 2550 B.c.

Charcoal from dark, ashy, preceramic level of Village 1. Comment (F.E.): dark ashy levels usually indicate a site belonging to final precotton period on central coast of Peru. Date fits well with this estimate.

\section{I-1229. Village 1, v-1131, Peru}

$3625 \pm 200$

1675 B.C.

Vegetable matter from stratigraphic cut in mound overlying preceramic Village 1. Found in stratigraphic position in natural Level 5 with pottery and corn. Comment (F.E.): date indicates level is preChavin or early Chavinoid.

\section{I-956. Site 4, v-1032, Peru}

$4300 \pm \mathbf{5 0 0}$

\section{B.C.}

Charcoal from small refuse mound at Site 4 . Site is on southern bluff overhanging bed of river, close to Village 1.

\section{I-1290. Village 6, v-1176, Peru}

Charcoal from deepest natural level in stratigraphic test cut. Comment (F.E.): probably one of last preceramic, cotton-yielding sites. 
I-1192. Village 20, v-1162, Peru

Reed mat from funeral bundle at Village 20 in northern range of hills closing Chilca canyon (12 $28^{\prime} \mathrm{S}$ Lat, $76^{\circ} 4548^{\prime \prime} \mathrm{W}$ Long). Comment (F.E.) : age is normal for "Lomas" settlers.

\section{I-1091. Village 74, v-1134, Peru}

$4310 \pm 275$

Charcoal from refuse at cotton-yielding site of what had been a village of reed huts built over low rectangular stone walls. Comment (F.E.): date indicates site may be one of oldest cotton-yielding villages in Chilca area.

\section{I-980. Village 85, v-1065, Peru}

$$
585 \pm 100
$$

Corn (cob) from Village 85 in Chilca canyon. Comment (F.E.) : level is expected to be post-Tiahuanacoid and pre-Inca. Date fits well with this interpretation. Grave had been looted and stratigraphic position of sample is uncertain. Comment (F.E.): patterns on fabric are typical "Huaca Malena" period, Style II, rather than Tiahuanacoid.

\section{I-1444. Site 156, v-1213, Peru}

$3600 \pm 140$

Charcoal from black ashy refuse level in test pit at Site $156\left(12^{\circ}\right.$ $27^{\prime} 36^{\prime \prime} \mathrm{S}$ Lat, $76^{\circ} 43^{\prime} 18^{\prime \prime} \mathrm{W}$ Long). Site is preceramic and yielded twined cotton fabric. Comment (F.E.): age obtained, together with black ashy refuse, indicates a site of final preceramic period.

\section{I-1435. Site 156, v-1217, Peru}

$3520 \pm 125$

1570 B.c.

Vegetable matter from inside small refuse mound at Site 166, a preceramic site yielding twined cotton fabrics. Site is located on lateral branch of Chilca on the way to a pass leading to Quebrada de los Perdidos, $40 \mathrm{~km}$ inland.

\section{I-1476. Village 219, v-1168, Peru}

$400 \pm 100$

Charcoal from inside stone house at Village $219\left(12^{\circ} 16^{\prime} 30^{\prime \prime} \mathrm{S}\right.$ Lat, $76^{\circ} 24^{\prime} 18^{\prime \prime} \mathrm{W}$ Long). No stratigraphy was evidenced, but brown circleimpressed pottery was associated with sample. Comment (F.E.): pottery style is usually contemporary with Cusquenian influences. Date obtained supports this assumption.

\section{I-1124. Village 93, v-1156, Peru}

Charcoal from test pit at Village 93. Reed twined fabrics, but no cotton, were recovered. Pit revealed black ashy refuse similar to that found at similar sites. Comment (F.E.): date indicates that site may be one of the last pre-cotton sites in Chilca area. 
I-1185. Village 107, v-1158, Peru

A.D. 1580

$370 \pm 120$

Vegetable matter from inside one of the houses of Village 107, large village near beach at foot of Cerro Santa Maria (12 $26^{\prime} 24^{\prime \prime} \mathrm{S}$ Lat, $76^{\circ}$ $46^{\prime} 36^{\prime \prime} \mathrm{W}$ Long). Comment (F.E.): sample may date a refuge village. A large group of people apparently lived for a short time at the site. Water is available, but very deep. Site is possibly early Hispanic.

\section{I-1479. Village 137, v-1235, Peru}

$700 \pm 120$

Charcoal from Natural Level 2 in Village 137. Comment (F.E.): typical age for late Central Coast culture which lasts during Inca influence.

\section{I-1480. Village 143, v-1234, Peru}

$1005 \pm 125$

Woven fabric from grave within adobe house at Village 143.

\section{I-1248. Village 224, v-1167, Peru}

$635 \pm 150$

Charcoal from refuse inside house of Village $224\left(12^{\circ} 19^{\prime} 36^{\prime \prime} S\right.$ Lat, $76^{\circ} 31^{\prime} 12^{\prime \prime} \mathrm{W}$ Long). Site is high upstream (alt $1130 \mathrm{~m}$ ), but still within coastal climate area. Sample was associated with brown pottery with impressed circles and black and red post-fired painted pottery typical of pre-Inca style on central coast.

\section{I-1397. Village 235, v-1196, Peru}

$1830 \pm 120$

Charcoal from inside house containing Llapa Llapa pre-fired painted pottery at village 235 , halfway up Chilca canyon $\left(12^{\circ} 24^{\prime} 48^{\prime \prime} \mathrm{S}\right.$ Lat, $76^{\circ}$ $30^{\prime} 54^{\prime \prime} \mathrm{W}$ Long). Comment (F.E.): age may indicate a final phase for Central Coast culture which used Llapa Llapa pottery, post-fired, painted in the early phase and later pre-fired.

\section{I-1560. Village 519, v-1272, Peru}

$950 \pm 110$

Vegetable matter from refuse mound at Village 519, a Tiahuanacoid pottery-yielding site in Chilca canyon (12 $32^{\prime} 58^{\prime \prime} \mathrm{S}$ Lat, $76^{\circ} 42^{\prime} 56^{\prime \prime} \mathrm{W}$ Long).

\section{I-1184. Site 105-2, V-1159, Peru}

$3040 \pm 200$

Charcoal from deepest level inside refuse mound at Site 105-2, a cliff overhanging the ocean ( $12^{\circ} 26^{\prime} 42^{\prime \prime} \mathrm{S}$ Lat, $76^{\circ} 46^{\prime} 42^{\prime \prime} \mathrm{W}$ Long) in Chilca area. No cotton, pottery, or corn was visible in test pit.

\section{I-810. Las Colinas, Peru}

Charcoal from deepest Chavinoid level at interface with preceramic refuse, at Village 9, "Las Colinas", on slope of hill overlooking Ancon 
( $11^{\circ} 46^{\prime} 45^{\prime \prime} \mathrm{S}$ Lat, $76^{\circ} 11^{\prime} 00^{\prime \prime} \mathrm{W}$ Long), on central coast of Peru. Twined fabrics are present in level sampled. Coll. by Ramiro Matos, Univ. of Huancayo, Peru; subm. 1963 by Frederic Engel. Comment (F.E.): twined fabrics are not found in Chavinoid refuse and sample may have been slightly contaminated by preceramic refuse. Age is not far from Chilca 24 (GX-203, $3610 \pm 80$, GX-275, $3510 \pm 70$, Geochron., unpub.).

\section{I-1562. Chillon River, Peru}

$1500 \pm 120$

Mixture of charcoal, corn, and fabric, from Village 28 on $\mathrm{N}$ bluff of Chillon River, $1 \mathrm{~km} \mathrm{E}$ of the sea ( $11^{\circ} 56^{\prime} 40^{\prime \prime} \mathrm{S}$ Lat, $77^{\circ} 06^{\prime} 44^{\prime \prime} \mathrm{W}$ Long), ca. $10 \mathrm{~km} \mathrm{~N}$ of Lima International Airport, on central coast of Peru. Found in stratigraphic position and in association with interlocking pottery of Playa Grande type. Coll. and subm. 1964 by Frederic Engel. Comment (F.E.): provides date for this pottery and also for period of some wall paintings associated with similar pottery at nearby Cerro Culebras.

\section{Omas series, Peru}

Samples from drainage area of the Omas, an intermittent river, on central coast of Peru (Engel, 1963a). Coll. and subm. 1964 by Frederic Engel.

\section{I-1230. Village 5, v-1164, Peru}

$2890 \pm 210$

940 B.c.

Vegetable material from Refuse Level 2 in an adobe house in Village 5 ( $12^{\circ} 45^{\prime} 02^{\prime \prime} \mathrm{S}$ Lat, $76^{\circ} 33^{\prime} 58^{\prime \prime} \mathrm{W}$ Long). House from which sample was taken contained Chavinoid pottery. Comment (F.E.) : fairly typical Chavin age.

\section{I-1389. Site 25, v-130, Peru}

I-1381. Site 25, 0-3008, Peru

Fabric from bundle in Grave 1 at Site 25, a small adobe structure close to the Omas $\left(12^{\circ} 45^{\prime} 18^{\prime \prime} \mathrm{S}\right.$ Lat, $76^{\circ} 24^{\prime} 33^{\prime \prime} \mathrm{W}$ Long), ca. $3 \mathrm{~km} \mathrm{E}$ of the sea. Comment (F.E.): checker pattern of fabric is typical of Chavin horizon on central coast of Peru. Sample was submitted in two separate sections as "blind split." Dates on two fractions show good agreement.

\section{I-1231. Mound 302, v-657, Peru}

$\mathbf{5 4 4 0} \pm 250$

Vegetable matter from Grave 6, same grave in same mound as I-1382. Comment (F.E.): age seems too old for corn and pottery. Contamination may have occurred from underlying preceramic mound. 
I-1380. Mound 302, 0-6475, Peru

Fabric from Grave 7, in Mound 302, described in I-1382. Grave contained corn and Chavinoid pottery. Comment (F.E.): dates early phase of Chavin horizon. Probably a more reliable age than those on I-1231 and I-1382 from same mound.

\section{I-1382. Mound 302, 0-5577, Peru}

$4320 \pm 120$

2370 B.c.

Fabric from Grave 6, an adobe structure with rooms, earth columns and a staircase, in Mound 302 (12 $46^{\prime} 29^{\prime \prime} \mathrm{S}$ Lat, $76^{\circ} 34^{\prime} 45^{\prime \prime} \mathrm{W}$ Long), ca. $3 \mathrm{~km} \mathrm{E}$ of the sea. Grave contained corn and pottery. Floor plan resembles that of temple of Punkuri Bajo in Napana Valley on $\mathrm{N}$ coast of Peru. Comment (F.E.): age seems somewhat old for corn and pottery. Mound was built over a preceramic refuse mound which may have caused some contamination. See also I-1380, I-1231 from same mound.

\section{Paracas series, Peru}

Samples from sites on Paracas Peninsula on S coast of Peru. Coll. and subm. 1963 to 1964 by Frederic Engel (Engel, 1963a).

\section{I-1311. Village 96, v-1178, Peru}

$8830 \pm 190$

Reed mat from burial near house at Village 96 on eastern shore of Paracas Bay ( $13^{\circ} 5 \mathrm{I}^{\prime} 18^{\prime \prime} \mathrm{S}$ Lat, $76^{\circ} 15^{\prime} 00^{\prime \prime} \mathrm{W}$ Long). Comment (F.E.): village contains gourds and a tuber, possibly a kind of yuca. Date should establish arrival of incipient agriculture on $\mathrm{S}$ coast of Peru.

\section{I-957. Cabezas Largas, v-817, Peru}

$1695 \pm 130$

Vegetable matter from Stratigraphic Cut VI in Cabezas Largas on

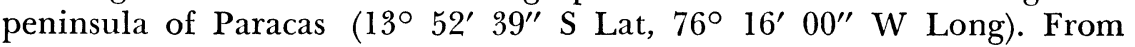
Level 1E, inside house built on top of older structures. Comment (F.E.): dates the Nazca 2 or 3 reoccupation of proto-Nazca stone village of Cabezas Largas.

I-1340. Cabezas Largas, v-1174, Peru

$$
2360 \pm 215
$$

Algal material cementing walls of proto-Nazca stone compounds of Cabezas Largas. From same site and stratigraphic cut as I-957. Buildings contain quantities of proto-Nazca pottery. Comment (F.E.): age seems slightly old for proto-Nazca structures.

\section{MISCELLANEOUS SAMPLES}

\section{Gas "seep" series, SE U.S.A.}

Samples of marsh gas, mostly methane, from gas "seeps" in ponds in Georgia and Alabama. Samples were obtained by agitating bottom sedi- 
ments in the ponds and collecting the released gas bubbles by water displacement in a 5 gallon glass jug. Sediments are presumably of recent age. Coll. 1963 by J. C. Wilson; subm. 1964 by D. R. Baker, Marathon Oil Co., Littleton, Colorado.

\section{I-1146. Cobb Creek, Georgia}

From pond on Cobb Creek, $5 \mathrm{mi}$ S of Vidalia on State Highway 15 and $11 / 4 \mathrm{mi} \mathrm{W}$ at Cobb Creek crossing ( $32^{\circ} 10^{\prime} \mathrm{N}$ Lat, $82^{\circ} 25^{\prime} \mathrm{W}$ Long), Toombs County, Georgia. Comment (D.R.B.): methane fraction was separated from other minor components in collected gas prior to analysis on this and other samples of the series. Age suggests that methane was formed by bacterial decomposition of recent plant material which accumulated in bottom sediments.

\section{I-1148. Rocky Creek, Georgia}

From a pond on Rocky Creek at Rocky Creek Crossing, 1 mi SE of Vidalia, Toombs County, Georgia (32. $10^{\prime} \mathrm{N}$ Lat, $82^{\circ} 25^{\prime} \mathrm{W}$. Long). Comment (D.R.B.) : see I-1146 for sample treatment. $\delta \mathrm{C}^{14}$ was +250 indicating that methane was formed by bacterial activity probably utilizing plant and other carbonaceous material formed since the increase in atmospheric $\mathrm{C}^{14}$ content due to atmospheric nuclear explosions.

\section{I-1147. Swift Creek, Georgia}

$715 \pm 120$

From pond on Swift Creek 13/4 mi NE of Higgston, Montgomery County, Georgia. Comment (D.R.B.): see I-1146 for sample treatment. Date suggests that methane was formed by bacterial decomposition of recent plant material, although the significantly older age than that observed for I-1146 suggests that some ancient carbonaceous material may also have been used.

I-1149. Sealy Springs well, Alabama

From Sealy Springs Well, Cottonwood, Houston County, Alabama. Well yielding salt water and natural gas, probably from Upper Cretaceous Eutaw sandstone. Comment (D.R.B.): sample submitted as control. Infinite age as expected.

\section{I-1150. Maxie Gas Field, Mississippi}

From Lower and Upper Cretaceous, and Eocene formations in Maxie Gas Field, Forrest County, Mississippi. Comment (D.R.B.) : control sample yielding infinite age as expected.

Date lists:

\section{REFERENCES}

$\begin{array}{ll}\text { Isotopes I } & \text { Walton, Trautman, and Friend, } 1961 \\ \text { Isotopes II } & \text { Trautman and Walton, 1962 } \\ \text { Isotopes III } & \text { Trautman, 1963 }\end{array}$ 


$\begin{array}{ll}\text { Isotopes IV } & \text { Trautman, 1964 } \\ \text { LaJolla IV } & \text { Hubbs, Bien, and Suess, 1965 } \\ \text { Lamont V } & \text { Olson and Broecker, 1959 } \\ \text { Michigan V } & \text { Crane and Griffin, 1960 } \\ \text { Michigan VIII } & \text { Crane and Griffin, 1963 } \\ \text { Socony Mobil I I } & \text { Bray and Burke, 1960 } \\ \text { USGS V } & \text { Rubin and Alexander, 1960 } \\ \text { USGS VII } & \text { Ives, Levin, Robinson, and Rubin, 1964 } \\ \text { Yale VII } & \text { Stuiver and Deevey, 1962 } \\ \text { Yale VIII } & \text { Stuiver, Deevey, Jr., and Rouse, 1963 }\end{array}$

Andrews, J. T., 1963, The cross-valley moraines of north central Baffin Island: A quantitative analysis: Geographical Bull. [Ottawa], no. 20.

Berger, Rainer, Harney, Amos G., and Libby, W. F., 1964, Radiocarbon dating of bone and shell from their organic components: Science, v. 144, no. 3621, p. 999-1001.

Black, R. F., 1964, Gubik formation of Quaternary age in northern Alaska: U. S. Geol. Survey Prof. Paper 302-C, p. 59-91.

Bray, E. E., and Burke, W. H., Jr., 1960, Socony-Mobil radiocarbon dates I: Am. Jour. Sci. Radioc. Supp., v. 2, p. 97-111.

Brown, J., 1964, Ice-wedge chemistry and related frozen ground processes: Proc. Internat. Permafrost Conf.

Butzer, K. W., 1962, Pleistocene stratigraphy and prehistory in Egypt: Quaternaria [Rome], v. 6, p. 451-477.

Colinvaux, P. A., 1964, Origin of ice ages: Pollen evidence from arctic Alaska: Science, v. 145, p. $707-708$.

Coulter, H. W., Hussey, K. M., and O'Sullivan, J. B., 1960, Radiocarbon dates relating to the Gubik formation, northern Alaska: U. S. Geol. Survey Prof. Paper 400-B, p. $350-351$.

Craig, B. G., 1961, Surficial geology of northern district of Keewatin, Northwest Territories: Canada Geol. Survey Paper 61-5.

Cranc, H. R., and Griffin, J. B., 1960, University of Michigan radiocarbon dates V: Am. Jour. Sci. Radioc. Supp., v. 2, p. 3-48. p. $228-253$.

Cressman, L. S., 1956, Klamath Prehistory: the prehistory of the culture of the Klamath Lake area, Oregon: Am. Philos. Soc., Trans., v. 46, pt. 4.

Cressman, L. S. et al., 1942, Archaeological researches in the Northern Great Basin: Carnegie Inst. of Washington, pub. 538.

Douglas, L. A., and Tedrow, J. C. F., 1960, Tundra soils of arctic Alaska: Internat. Congress Soil Sci., 7th, Transactions, v. 4, p. 291-304.

Easterbrook, D. J., 1962, Pleistocene sequence on Whidbey Island (Abs) : N. W. Sci., v. 36 , no. 4 .

1963a, Late Pleistocene glacial events and relative sea level changes in the Northern Puget Lowland, Wash: Geol. Soc. Am. Bull., v. 74, p. 1465-1484.

1963b, Late Pleistocene glaciation of Whidbey Island (Abs): Geol. Soc. Am. Spec. Paper 73.

1965, Guidebook for Field Conference J, Pacific Northwest: Internat. Congress for Quaternary Research, p. 68-75.

Engel, Frederic, 1963a, Datations àlaide du radio-carbone 14 et problèmès de la préhistoire du Pérou: Jour. de la Soc. des Américanistes, N.S., tome 52, p. 101-132. 1963b, Notes relatives à des explorations archéologiques à Paracas et sur la cote sud du Pérou: Travaux de l'Institut rrançais d'Etudes Andines, tome 9, p. 1-72.

1963c, A preceramic settlement on the central coast of Peru: Asia, Unit 1:

Trans. Am. Philos. Soc., New Series, v. 53, pt. 3.

1964, El precerámico sin algodón en la costa del Perú: Actas y Memorias,

v. 3, XXXV Congreso Internat. de Americanistas, Mexico-1962, p. 141-152. 
Fairbridge, R. W., 1960, The changing level of the sea: Scientific American, v. 202, p. 70-79.

Fairbridge, R. W., 1960, The changing level of the sea: Scientific American, v. 202, p. 70-79.

Grayson, J. F., 1956, The postglacial history of vegetation and climate in the Labrador-Quebec region as determined by palynology: Ph.D. thesis, Univ. of Michigan.

Gross, M. G., Gucluer, S. M., Creager, J. S., and Dawson, W. A., 1963, Varved marine sediments in a stagnant marine basin: Science, v. 141, p. 918-919.

Hansen, H. P., and Mackin, J. H., 1949, A pre-Wisconsin forest succession in the Puget lowland, Washington: Am. Jour. Sci., v. 247, p. 833-855.

Harrison, D. A., 1964, A reconnaissance glacier and geomorphological survey of the Duart Lake area, Bruce Mountains, Baffin Island: Geographical Bull. [Ottawa],
no. 22.

Haynes, V., and Agogino, G., 1960, Geological significance of a new radiocarbon date from the Lindenmeier Site: Denver Mus. of Nat. History, Proc., no. 9, 23 p.

Heusser, C. J., 1963, Postglacial palynology and archaeology in the Naknek River Drainage area, Alaska: Am. Antiquity, v. 29, p. 74-81.

Hewes, G. W., 1963, Gezira Dabarosa: Report of the University of Colorado Nubian expedition, 1962-63 Season: KUSH, v. 12.

Hubbs, C. L., Bien, G. S., and Suess, H. E., 1965, La Jolla natural radiocarbon measurements IV: Radiocarbon, v. 7, p. 66-117.

Irwin, Cynthia, Irwin, Henry, and Agogino, George, 1962, Wyoming muck tells of battle: ice age man vs. mammoth: Natl. Geog. Magazine, v. 121, no. 6, p. 828-837.

Ives, J. D., 1962, Indications of recent extensive glacierization in north-central Baffin Island, N. W. T.: Jour. Glaciology, v. 4, no. 32, p. 197-206.

1964, Deglaciation and land emergence in northeastern Foxe Basin: Geographical Bull. [Ottawa], no. 21.

Ives, J. D., and Andrews, J. T., 1963, Studies in the physical geography of north central Baffin Island, N. W. T.: Geographical Bull. [Ottawa], no. 19, p. 5-48.

Ives, P. C., Levin, Betsy, Robinson, R. D., and Rubin, Meyer, 1964, U. S. Geological Survey radiocarbon dates VII: Radiocarbon, v. 6, p. 37-76.

Judson, S., 1963, Erosion and deposition of Italian Stream Valleys during historic time: Science, v. 140, p. 898-899.

L $\varnothing$ ken, Olav H., and Leahy, Edward J., 1964, Small moraines in southeastern Ontario: Canadian Geographer, v. 8, no. 1, p. 10-21.

Livingstone, D. A., 1955, Pollen profiles from arctic Alaska: Ecology, v. 36, p. 587-600.

McMichael, E. V., and Mairs, O. L., 1963, Salvage excavation of the Leslie Mound (46-Pu-3) Putnam County, West Virginia: West Virginia Archeologist, no. 15, p. 23-40.

Morrison, A., 1963, Landform studies in the middle Hamilton River area, Labrador: Arctic, v. 16, no. 4, p. 273-275.

Nordström, Hans, 1962, Excavations and survey in Faras, Argin and Gezira Dabarosa: KUSH, v. 10, p. 34-58.

Olson, E. A., and Broecker, W. S., 1959, Lamont natural radiocarbon measurements V: Am. Jour. Sci. Radioc. Supp., v. 1, p. 1-28.

Porter, S. C., 1964, Late Pleistocene glacial chronology of north-central Brooks Range, Alaska: Am. Jour. Sci., v. 262, p. 446-460.

Rubin, Meyer, and Alexander, Corrinne, 1960, U. S. Geological Survey radiocarbon dates V: Am. Jour. Sci. Radioc. Supp., v. 2, p. 129-185.

Singh, G., 1964, Studies of the Late Quaternary vegetational history and relative sealevel changes in Co. Down, N. Ireland: Ph.D. thesis, Queen's Univ., Belfast, U. K.

Singh, G., and Smith, A. G., 1965, The post-glacial marine transgression in N. Ireland. Conclusions from estuarine and 'raised beach' deposits: a contrast: Palaeobotanist, v. 14 (in press).

Stuiver, Minze, and Deevey, E. S., 1962, Yale natural radiocarbon measurements VII: Radiocarbon, v. 4, p. 250-262. 
Stuiver, Minze, Deevey, E. S., Jr., and Rouse, Irving, 1963, Yale natural radiocarbon measurements VIII: Radiocarbon, v. 5, p. 312-341.

Tolonen, Kimmo, 1963, UUber die Entwicklung eines nordkarelischen Moores im Lichte der $\mathrm{C}^{14}$-Datierung. Das Moor Prohtiinsuo in Ilomantsi (Ost-Finnland): Arch. Soc. "Vanamo", v. 18, no. 1, p. 41-57.

Trautman, M. A., 1963, Isotopes, Inc. radiocarbon measurements III: Radiocarbon, v. 5 , p. $62-79$.

1964, Isotopes, Inc. radiocarbon measurements IV: Radiocarbon, v. 6, p. $269-279$.

Trautman, M. A., and Walton, Alan, 1962, Isotopes, Inc. radiocarbon measurements II: Radiocarbon, v. 4, p. 35-42.

Vasari, Yrjö, 1962, A study of the vegetational history of the Kuusamo district during the Late-Quaternary period I: Ann. Bot. Soc. "Vanamo", v. 33, no. 1, p. 1-140.

1963, Studies on the vegetational history of the Kuusamo district during the Late-Quaternary period: Arch. Soc. 'Vanamo', v. 18, no. 2, p. 121-127.

Walton, Alan, Trautman, M. A., and Friend, J. P., 1961, Isotopes, Inc. radiocarbon measurements I: Radiocarbon, v. 3, p. 47-59.

Weber, F. R., and Péwé, T. L., 1961a, Engineering geology problems in the YukonKoyukuk Lowland, Alaska: in Short Papers in the Geologic and Hydrologic Sciences: U. S. Geol. Survey Prof. Paper 424-D, p. 371-373.

1961b, Surficial and engineering geology of the central part of the Yukon. Koyukuk Lowland, Alaska: U. S. Geol. Survey Open-file Report. 